\title{
\#USGS

\section{Preliminary estimate of the amplification of possible earthquake ground motion at a site in Charleston County, South Carolina}

by Russell L. Wheeler ${ }^{1}$ and Chris H. Cramer ${ }^{2}$

Open-File Report 00-0484

2000

This report is preliminary and has not been reviewed for conformity with U.S. Geological Survey editorial standards or with the North American Stratigraphic Code. Any use of trade, firm, or product names is for descriptive purposes only and does not imply endorsement by the U.S. Government.

U.S. DEPARTMENT OF THE INTERIOR

U.S. GEOLOGICAL SURVEY

${ }^{1}$ Golden, Colorado

${ }^{2}$ Memphis, Tennessee 


\begin{abstract}
We estimate site amplification at the location of a proposed bridge near Charleston, South Carolina. Model calculations indicate that amplification at periods of $1 \mathrm{~s}$ and longer is likely to be strongly influenced by the effects of a large contrast in shear-wave velocity at a depth of approximately $1 \mathrm{~km}(3,000 \mathrm{ft})$. On-site borehole data, regional geological and geophysical information, and data from a geologically similar setting near Memphis, Tennessee allowed us to estimate profiles of shear-wave velocity, shear-wave attenuation, and density from ground level down to metamorphic and igneous rocks that are approximately $3 \mathrm{~km}(9,500 \mathrm{ft})$ beneath the site. We modeled amplifications that would be produced at the surface and at the top and bottom of the Cooper Marl. Amplification estimates that are based only on the shallow shear-wave

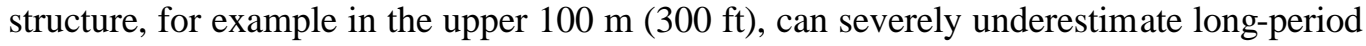
amplification at the site. Additional modeling could help determine whether new data should be collected, to resolve remaining uncertainties about likely amplification.
\end{abstract}

\title{
INTRODUCTION
}

\section{Background}

The South Carolina Department of Transportation (SCDOT) is supervising a competitive bidding process to design and build a bridge across the Cooper River between Charleston and Mount Pleasant, South Carolina. SCDOT is advised by the firm of Lindbergh and Associates on earthquake hazards that might affect the proposed bridge. SCDOT requested a report from Lindbergh and Associates, for equal and simultaneous distribution to the competing firms ("A limited study of seismic design criteria for the new Cooper River bridge, Charleston, South Carolina", dated September 7, 2000; hereafter cited as C. Lindbergh, written commun, 2000). The USGS was requested to assess the potential for amplification of possible earthquake shaking by the stratigraphic column that underlies the site of the proposed bridge, with emphasis on periods of $1 \mathrm{~s}$ and longer. Prior commitments prevented us from including the following analyses in the report to SCDOT except as oral communications, and publication of this open-file report remedies that omission.

\section{Purpose}

It has long been known that long-period amplification in the Charleston vicinity depends strongly on the effects of a velocity contrast at a depth of approximately $1 \mathrm{~km}$ (Chapman and others, 1990). The accurate characterization of likely amplification from the full stratigraphic column would require subsurface data from depths as great as $1-3 \mathrm{~km}(3,000-10,000 \mathrm{ft})$ beneath the site, as described later ("Shear-wave stratigraphy"). As far as we are aware, these deep data do not exist. Accordingly, our analyses compare the amplifications that would result from various hypothetical stratigraphic columns that are consistent with regional geological and geophysical information, some of it collected tens of kilometers (miles) from the site. Our purpose is to provide independent, linear analyses to allow SCDOT and the competing firms to decide which additional analyses may be needed, and whether they should collect deep data at the site. Any existing or future deep data from the bridge site would supersede our estimates. The degree to which our results may apply to other sites in the South Carolina Coastal Plain depends on the degree to which subsurface lithologies, thicknesses, and depths resemble those at the Cooper River bridge site. The degree of resemblance between the bridge site and other sites can be determined only with site-specific data from the other sites. 


\section{SHEAR-WAVE STRATIGRAPHY}

The stratigraphic column at the site and in the surrounding region consists of three intervals that are separated by two unconformities. Downward from the surface, these five elements are (1) Cenozoic and Upper Cretaceous sediments of the Coastal Plain, (2) a preCretaceous unconformity, (3) Jurassic and Triassic basalts, hard sedimentary rocks including red beds, or both, (4) a deeper, basement unconformity, and (5) hard, Paleozoic, metamorphic and igneous rocks (basement). Information not available in 1990 allows the following stratigraphic column to be specified in more detail than that used for the regional analysis of Chapman and others (1990); our results are consistent with theirs.

The elevations at and near the site are negligible for the purposes of estimating amplification -- 2-14 ft (0.6-4.3 m) above sea level. Accordingly, we will distinguish between depths below ground level and elevations below sea level, but we will treat them as equal in our calculations.

The seismic-refraction analyses of Ackermann (1983) showed that the pre-Cretaceous and basement unconformities strike northeast and dip gently southeast near Charleston and probably at the site. Both unconformities maintain this general orientation throughout a broad, northeast-trending area that is approximately $80 \mathrm{~km}(50 \mathrm{mi})$ long and 20-30 km (12-19 mi) wide, and which extends from southwestern Charleston Co. northeastward to central Berkeley Co. Northwest of this elongated area, the pre-Cretaceous and especially the basement unconformities have more complex shapes that indicate one or both unconformities may have been folded, faulted, or both, before deposition of the overlying undeformed or less deformed strata (Ackermann, 1983). As far as we know, all wells that penetrate the pre-Cretaceous unconformity within several tens of kilometers (miles) of the site are in the northwestern area of more complex structure. This includes the Clubhouse Crossroads Nos. 1-3 wells (Gohn and others, 1977, 1983). Accordingly, we have used reports on these and similar deep wells to infer the types and sequences of rocks that are likely to underlie the site at depths greater than approximately $100 \mathrm{~m}$ (300-400 ft). However, we estimated depths to the two unconformities beneath the site from other information closer to the site.

\section{Cenozoic and Upper Cretaceous sediments of the Coastal Plain}

The upper part of the Cenozoic and Upper Cretaceous sediments is well characterized by C. Lindbergh (written commun., 2000). Visual examinations of samples from numerous shallow borings at and near the site indicate that the sandy sediments near the surface are underlain at depths of 38-58 ft (12-18 m) below ground level by the stiff, higher-velocity Cooper Marl of Eocene-Oligocene age (Gohn, 1977, 1988). The single well near the site that penetrated the base of the marl, boring DS-1, indicates that the marl extends to a depth of $285 \mathrm{ft}(87 \mathrm{~m})$. The marl is underlain by $200-300 \mathrm{~m}(600-1,000 \mathrm{ft})$ of lower Tertiary limestone, clay, and sand; approximately

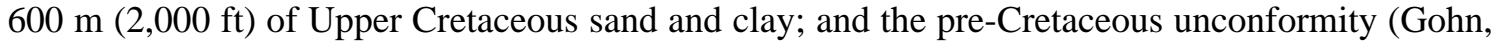
1977, 1988; Campbell and Gohn, 1994; Bybell and others, 1998).

Amplification is governed largely by shear-wave velocity (Vs). We estimated Vs through the upper part of the Coastal Plain sediments from a Vs profile that was measured at the site in borehole DS-1 by Redpath Geophysics (C. Lindbergh, written commun., 2000). The rows in Table 1 that summarize layers 1-6 show the depth intervals and Vs values that we used in our analyses of the upper part of the Coastal Plain sediments. We generalized the profile slightly, by averaging or deleting thin layers in ways that would not affect our amplification estimates. The boundaries between the layers in Table 1 resemble, but may differ slightly from, boundaries 
between stratigraphic units that were identified by geologic examination of cores, cuttings, and well logs. For example, Table 1 and the previous paragraph give slightly different depths for the top and bottom of the Cooper Marl. The slight differences occur because the physical properties that determine Vs do not always match the color, grain size, degree of cementation, fossils, and the like that determine the contacts that a geologist would observe between geological formations.

\begin{tabular}{|c|c|c|c|c|c|}
\hline \multicolumn{6}{|c|}{ Table 1. Shear-wave (Vs) profile used in analyses } \\
\hline Layer & $\begin{array}{l}\text { Depth } \\
\text { (m) }\end{array}$ & $\begin{array}{l}\text { Depth } \\
\text { (ft)* }\end{array}$ & Vs $(\mathbf{m} / \mathbf{s})$ & Vs $(\mathbf{f t} / \mathbf{s})^{*}$ & Notes (see text) \\
\hline \multicolumn{6}{|c|}{ From borehole DS-1 } \\
\hline 1 & $0-5$ & $0-16$ & 76 & 250 & \multirow{3}{*}{$\begin{array}{l}\text { Sandy sediments (Quaternary-upper } \\
\text { Tertiary) of the Coastal Plain }\end{array}$} \\
\hline 2 & $5-12$ & $16-40$ & 213 & 700 & \\
\hline 3 & $12-24$ & $40-80$ & 335 & 1,100 & \\
\hline 4 & $24-66$ & $80-215$ & 457 & 1,500 & \multirow[t]{2}{*}{ Cooper Marl (Eocene-Oligocene) } \\
\hline 5 & $66-85$ & $215-280$ & 655 & 2,180 & \\
\hline 6 & $\begin{array}{l}85- \\
110^{* *}\end{array}$ & $\begin{array}{l}280- \\
360 * *\end{array}$ & 762 & 2,500 & $\begin{array}{l}\text { Limestone, clay, and sand (lower } \\
\text { Tertiary) of the Coastal Plain }\end{array}$ \\
\hline \multicolumn{6}{|c|}{ From regional geological and geophysical information } \\
\hline 7 & $110-808$ & $\begin{array}{l}360- \\
2,650 \\
\end{array}$ & \begin{tabular}{|l|}
$762-$ \\
1,300 \\
\end{tabular} & $\begin{array}{l}2,500- \\
4,300\end{array}$ & $\begin{array}{l}\text { Sand and clay (lower Tertiary-Upper } \\
\text { Cretaceous) of the Coastal Plain }\end{array}$ \\
\hline$* * *$ & 808 & 2,650 & \multicolumn{3}{|c|}{ Pre-Cretaceous unconformity } \\
\hline 8 & $\begin{array}{l}808- \\
2,890\end{array}$ & $\begin{array}{l}2,650- \\
9,480\end{array}$ & $\begin{array}{l}2,900- \\
3,600\end{array}$ & $\begin{array}{l}9,500- \\
11,800\end{array}$ & $\begin{array}{l}\text { Basalts and hard sedimentary rocks, } \\
\text { including red beds (Jurassic and } \\
\text { Triassic) }\end{array}$ \\
\hline$* * *$ & 2,890 & 9,480 & \multicolumn{3}{|r|}{ Basement unconformity } \\
\hline 9 & $2,890-?$ & $9,480-?$ & 3,600 & 11,800 & $\begin{array}{l}\text { Paleozoic metamorphic and igneous } \\
\text { rocks (basement) }\end{array}$ \\
\hline
\end{tabular}

Between the bottom of the DS-1 profile and the pre-Cretaceous unconformity are some additional lower Tertiary sediments, which, in turn, are underlain by a greater thickness of Upper Cretaceous sediments. We have no site-specific data on Vs below the DS-1 profile. However, Mueller (submitted) and C. Mueller (written commun., August 2000) estimated regional amplification for the entire Atlantic and Gulf Coast Coastal Plain. He developed a set of generic Vs profiles for sediments above the pre-Cretaceous unconformity. To each of six exposed stratigraphic units, Mueller assigned a unit-specific value of the variable Vs30. Vs30 is Vs averaged over the uppermost $30 \mathrm{~m}$. Mueller determined the correlations between Vs30 and stratigraphic units from published data. Mueller then extrapolated Vs downward by increasing it exponentially with depth. We plotted the depth and Vs values at the bottom of the DS-1 profile $(110 \mathrm{~m}$ and $762 \mathrm{~m} / \mathrm{s}$, respectively) on the set of generic Vs profiles. Then we extrapolated this point downward, parallel to the bracketing generic profiles, to the depth that we estimate in the next subsection for the pre-Cretaceous unconformity at the site. For the shallow depths considered here, an exponential Vs profile would be approximately linear with depth. Accordingly, beneath the bottom of the DS-1 profile, we used a Vs profile that increases linearly from $762 \mathrm{~m} / \mathrm{s}$ at $110 \mathrm{~m}$ depth to $1.3 \mathrm{~km} / \mathrm{s}$ at the unconformity (Table 1 ). 
We also considered the alternative that Vs is constant at $762 \mathrm{~m} / \mathrm{s}(2,500 \mathrm{ft} / \mathrm{s})$ from the bottom of the DS-1 profile down to the pre-Cretaceous unconformity ("Comparison a" in a later section on amplification estimates). Well data favor this alternative (C. Lindbergh, written commun., 2000).

\section{Pre-Cretaceous unconformity}

The depth to the pre-Cretaceous unconformity is best estimated from the log of water well CHN-635, which is on Sullivan Island approximately $6 \mathrm{~km}(4 \mathrm{mi})$ southeast of the site (Campbell and Gohn, 1994). The well bottomed at approximately 2,541 ft (774 m) below sea level, in the Clubhouse Formation of early Late Cretaceous age. Correlation with the Clubhouse Crossroads No. 1 well, $31 \mathrm{~km}(19 \mathrm{mi})$ to the west-northwest of CHN-635, indicates that probably the bottom of CHN-635 is underlain, successively downward, by (1) a few tens of meters (yards) of thinly-bedded gray clays, silts, and sands of the rest of the Clubhouse Formation, (2) an additional few tens of meters (yards) of massive brown and gray clays and sands of the thinner Beech Hill Formation of earliest Late Cretaceous age, and (3) the pre-Cretaceous unconformity (Campbell and Gohn, 1994). Of 12 other wells in the vicinity whose logs are shown by Campbell and Gohn (1994), only one penetrates into the upper part of the Clubhouse Formation. However, G. Gohn (oral commun., August 2000) suggested that the unconformity probably is at an elevation of 2,600-2,700 ft below sea level beneath CHN-635. This suggestion is consistent with the gradual southeastward thickening of the Upper Cretaceous section above the Clubhouse Formation, as shown by all 14 well logs. Accordingly, we take the pre-Cretaceous unconformity to be at approximately $2,650 \mathrm{ft}(808 \mathrm{~m})$ below sea level at the bridge site (Table 1).

An independent estimate of the depth to the pre-Cretaceous unconformity comes from the seismic-refraction results of Ackermann (1983). Ackermann drew a structure contour map of the elevation of the unconformity. The contours are roughly straight and trend northeast in coastal South Carolina, although they are more curved farther inland. The closest refraction control points to the site are approximately $20 \mathrm{~km}(12 \mathrm{mi})$ to the southwest, along strike, and $15-20 \mathrm{~km}$ (10-12 $\mathrm{mi})$ to the northwest and northeast, across strike. If we project Ackermann's contours straight toward the site, the projection gives an elevation of approximately $1,025 \mathrm{~m}(3,400 \mathrm{ft})$ below sea level. If the contours curve between the nearest control points and the site, similarly to how they curve farther inland on Ackermann's (1983) map, then we estimate that the unconformity might be as shallow as $950 \mathrm{~m}(3,100 \mathrm{ft})$ or as deep as $1,150 \mathrm{~m}(3,800 \mathrm{ft})$ below sea level.

We prefer the elevation estimate of 2,650 $\mathrm{ft}(808 \mathrm{~m})$ below sea level, because it is based on data closer to the site. Calculations reported later show that our conclusions would not be altered significantly even if the unconformity were as deep as $1,150 \mathrm{~m}(3,800 \mathrm{ft})$ below sea level ("Comparison d" in a later section on amplification results). We consider a depth as great as $1,150 \mathrm{~m}$ to be unlikely.

\section{Jurassic and Triassic rocks}

We know of no evidence for the existence of Coastal Plain sediments beneath the preCretaceous unconformity. Known sedimentary rocks beneath the unconformity formed from sediments that were deposited in Triassic-Jurassic, fault-bounded rift basins that developed during the opening of the Atlantic Ocean (Gohn, 1988). Such rift basins underlie a large region around the site (Daniels and others, 1983), and associated faults have been interpreted from well, seismic reflection, seismic refraction, gravity, and aeromagnetic data (Talwani, 1977; Ackermann, 1983; Gohn and others, 1983; Hamilton and others, 1983; Schilt and others, 1983). 
The Jurassic and Triassic rocks beneath the pre-Cretaceous unconformity have much higher velocities than the younger Coastal Plain sediments above the unconformity. Clubhouse Crossroads wells Nos. 1-3 penetrated Jurassic basalts beneath the unconformity (Gohn and others, 1983; Gottfried and others, 1983). Logs of these wells and three others (Chowns and Williams, 1983; Gohn and others, 1983; C. Lindbergh, written commun., 2000) show that, typically, basaltic intervals alternate with intervals of hard sedimentary rocks that include red beds. The intervals of hard sedimentary rocks tend to be several times as thick as the basaltic intervals. From these well logs, seventeen basaltic intervals are 14-304 m (46-997 ft) thick, with a median

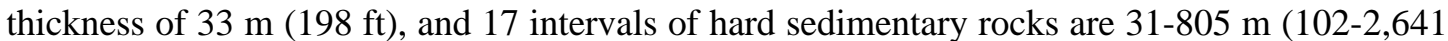
$\mathrm{ft}$ ) thick, with a median thickness of $201 \mathrm{~m}(659 \mathrm{ft})$. From the proprietary log of a well north of the Clubhouse Crossroads wells (C. Lindbergh, written commun., 2000), we use Vs $=3.6 \mathrm{~km} / \mathrm{s}$ $(11,800 \mathrm{ft} / \mathrm{s})$ for the basaltic intervals and Vs $=2.9 \mathrm{~km} / \mathrm{s}(9,500 \mathrm{ft} / \mathrm{s})$ for the intervals of hard sedimentary rocks (Table 1). These values are consistent with the results of Ackermann (1983), who used seismic refraction surveys to calculate the compressional-wave velocities, Vp, of the rocks immediately beneath the pre-Cretaceous unconformity at 23 locations northwest, north, and northeast of the site. We divide Ackermann's Vp values by 1.7 to obtain Vs values of $3.4 \mathrm{~km} / \mathrm{s}$ $(11,200 \mathrm{ft} / \mathrm{s})$ for the basalts and $2.5 \mathrm{~km} / \mathrm{s}(8,200 \mathrm{ft} / \mathrm{s})$ for the hard sedimentary rocks. These velocities are essentially the same as those from the proprietary well log, which we used in the analyses.

The well logs show that both basalts and hard sedimentary rocks are present between the pre-Cretaceous unconformity and the basement unconformity. Thus, the sedimentary column for this interval at the site could take any one of four forms. The column could be (1) entirely basalt, (2) entirely hard sedimentary rocks, (3) alternating layers of basalt and hard sedimentary rocks, with a basalt layer on top, or (4) alternating layers with hard sedimentary rocks on top. Evidence supporting this range of possibilities comes from the seismic refraction results of Ackermann (1983). He found that the rocks immediately beneath the pre-Cretaceous unconformity have $\mathrm{Vp}=$ $5.7 \mathrm{~km} / \mathrm{s}(18,800 \mathrm{ft} / \mathrm{s})$ in the northwest, in Dorchester Co., but that Vs decreases southeastward toward Charleston Co. and southernmost Berkeley Co., so that in these two counties the unconformity is underlain by rocks with $\mathrm{Vp}=4.2 \mathrm{~km} / \mathrm{s}(13,900 \mathrm{ft} / \mathrm{s})$. Ackermann interpreted this regional variation to indicate that the pre-Cretaceous unconformity is underlain by basalts in Dorchester Co. and by hard sedimentary rocks in Charleston and Berkeley Cos., with at least the uppermost basalts thinning southeastward from Dorchester Co. However, Behrendt and others (1983), Hamilton and others (1983), Schilt and others (1983), and Yantis and others (1983) used seismic reflection methods to trace the $\mathrm{J}$ reflector, which is interpreted to represent the uppermost basalt, over large distances with few interruptions, both onshore and offshore. Thus, in the absence of deep data from the site, we do not know which of the four possible stratigraphic columns exists at the site. The widespread presence of basalts in the region indicates that stratigraphic column (2), entirely hard sedimentary rocks, is the least likely of the four alternatives.

The proprietary well log mentioned two paragraphs previously shows that the preCretaceous unconformity north of the Clubhouse Crossroads wells is underlain by $8 \mathrm{~m}$ ( $26 \mathrm{ft}$ ) of rocks with $\mathrm{Vs}=1.4-2.2 \mathrm{~km} / \mathrm{s}$ and, beneath them, by several hundred meters (yards) of rocks with $\mathrm{Vs}=2.4-2.8 \mathrm{~km} / \mathrm{s}$. The $8 \mathrm{~m}$ of very low-velocity rocks are too thin to affect amplification.

However, the $2.4-2.8 \mathrm{~km} / \mathrm{s}$ rocks are much thicker. These thicker rocks could affect amplification in ways that can be determined only by additional modeling that is beyond the scope and purpose of this report (see "Introduction"). Whether such rocks are present at the bridge site can probably be determined only by deep geophysical or drilling studies. 


\section{Basement unconformity}

The depth to the deeper unconformity that separates the Jurassic-Triassic rocks from Paleozoic basement can be estimated by extrapolation of the refraction-determined depths of Ackermann (1983). He contoured depths to a layer with a Vp of $6.1 \mathrm{~km} / \mathrm{s}(20,000 \mathrm{ft} / \mathrm{s})$, which he interpreted as Paleozoic basement. His contours are roughly evenly spaced and parallel to the coast, and the contour nearest to Charleston is approximately $12 \mathrm{~km}(7 \mathrm{mi})$ northwest of the city. If this roughly uniform dip continues southeastward as far as the site, the unconformity would be approximately 2,890 m (9,480 ft) below sea level, and we used this depth in our analyses (Table $1)$.

\section{Basement}

Basement in the region of the site is Paleozoic metamorphic and igneous rocks of the rifted, eroded, and buried Appalachian Mountains. As mentioned in the preceding paragraph, Ackermann (1983) measured $\mathrm{Vp}=6.1 \mathrm{~km} / \mathrm{s}(20,000 \mathrm{ft} / \mathrm{s})$ for the rocks immediately beneath the basement unconformity at three localities. He interpreted these velocities to represent basement. We divided $\mathrm{Vp}$ beneath the unconformity by 1.7 to estimate $\mathrm{Vs}=3.6 \mathrm{~km} / \mathrm{s}(11,800 \mathrm{ft} / \mathrm{s})$ for Paleozoic basement (Table 1).

\section{AMPLIFICATION ESTIMATES}

Estimates of site amplification at the ground surface and at the top and bottom of the Cooper Marl relative to hard rock (the rocks beneath the pre-Cretaceous unconformity) have been made using a linear, Thomson-Haskell method program called RATTLE, which allows nonvertical incidence (Charles Mueller, oral and written communications, 2000). The estimates of site amplification are from linear calculations for vertically propagating shear-waves using onedimensional, layered models. Many of the site amplification estimates were checked using the relative-amplification portion of the program SHAKE (Schnabel and others, 1972). Relative amplification results from SHAKE are similar to those from RATTLE. Relative amplifications from a quarter-wavelength program by D. Boore (Robert A. Williams, oral and written communications, 2000) also provided similar results to SHAKE and RATTLE. The RATTLE program results are presented here because that program provides better long-period resolution than the other two programs.

Basic information input to these programs includes the shear-wave velocity (Vs) profile of Table 1 and estimates of shear-wave attenuation (Qs) and material density. Figures 1 and 2 show the Vs profile of Table 1 and its alternatives. Qs was taken to be 25 for the sediments in layers 1-5 of Table 1, based on in situ measurements of sediments of similar age and type in the Mississippi Embayment (Chen et al., 1994; Jose Pujol, 2000, oral and written communications). Qs was taken to be 50 in the sediments in layers 6-7. Rock Qs for layers 8-9 of Table 1 was set at 1000 (the results are insensitive to the precise value). Tests of the sensitivity of the results to the value of Qs for layers 1-3 were made and are presented below. Densities for layers 1-7 were set to $2.0 \mathrm{~g} / \mathrm{cc}$ and to $2.8 \mathrm{~g} / \mathrm{cc}$ for the rock layers 8-9 of Table 1 . These values are based on borehole density logs for similar materials in the Memphis, Tennessee area (Mississippi Embayment). The site amplification results are not very sensitive to these choices of density.

Comparisons have been made for (a) a constant Vs versus a linear gradient in layer 7 of Table 1 and Figure 2, (b) Qs alternatives of 25, 10, and 5 for layers 1-3 of Table 1, (c) site amplifications at the top and bottom of the Cooper Marl versus at the ground surface, (d) an 808 $\mathrm{m}(2,650 \mathrm{ft})$ versus an $1,150 \mathrm{~m}(3,800 \mathrm{ft})$ depth to the pre-Cretaceous unconformity, and (e) 
alternative Vs contrasts at and below the pre-Cretaceous unconformity (808 $\mathrm{m})$. These comparisons are presented below.

\section{Comparison (a): Constant Vs versus a Linear Gradient in Layer 7}

Figure 3 shows the effect on surface site amplification of using a linear Vs gradient in layer 7 (Figure 2) instead of using a constant Vs of $762 \mathrm{~m} / \mathrm{s}(2,500 \mathrm{ft} / \mathrm{s})$. First, note that the rapid variations in relative site amplification at lower frequencies are due to the presence of a strong Vs contrast at the pre-Cretaceous unconformity. That this is true is further illustrated in Comparison e below. Because of the uncertainty in our knowledge of the detailed Vs profile, the exact location of the peaks and troughs of the rapid variations in relative site response are difficult to predict. Thus, for conservatism, an upper envelope value of amplification instead of a mean value should be used from these plots as an estimate of site amplification. A better site-specific estimate would be obtained by propagating a suite of time-histories through a suite of velocity models using an equivalent linear (i.e., SHAKE) or a non-linear program, such as was done in the Geomatrix, 2000 report for this bridge site. Performing this more extensive analysis or a detailed review of a consultant's report is beyond the scope of this study.

Figure 3 indicates that the constant Vs model for layer 7 has slightly less relative amplification at frequencies above $2 \mathrm{~Hz}$ than the linear gradient model for layer 7 . This is due to

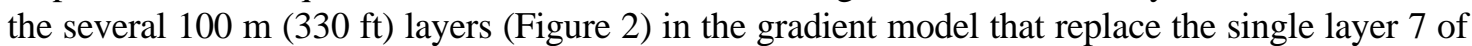
the constant Vs model. Below $2 \mathrm{~Hz}$, the upper envelopes of site amplification for the two alternatives are very similar, which shows insensitivity of these low frequency results to the Vs values in layer 7 of Table 1 .

\section{Comparison (b): Qs in layers 1-3}

Figures 4 and 5 are comparison figures for Qs in layers 1-3 of 25, 10 and 5. Actually, the Qs $=5$ model of Figures 4 and 5 only has a Qs of 5 in layer 1, with the Qs of layers 2 and 3 being 10. The effect of more shear-wave attenuation (lower Qs) in these upper layers is to lower the relative amplification for frequencies above $2 \mathrm{~Hz}$. This effect also occurs with non-linearity at large ground motions, because non-linearity also causes increased attenuation of seismic waves. However, below $2 \mathrm{~Hz}$ there is little or no effect from lower Qs, indicating little contribution to relative site response from the shallow Vs and Qs structure at these low frequencies.

\section{Comparison (c): Amplification at the Top and Bottom of Cooper Marl versus at the Ground Surface}

Figures 6-8 show site amplifications at the top of the Cooper Marl and are similar to Figures 3-5, respectively. The high frequency response is muted and the effect of variations in Qs near the surface is reduced, again showing the sensitivity of site amplification at high frequencies to shallow Vs structure.

Figures 9-11 are site amplification spectra at the bottom of the Cooper Marl like those at the surface (Figures 3-5) and the top of the Cooper Marl (Figures 6-8). Above $0.5 \mathrm{~Hz}$ (2 s period) the relative amplifications are more muted and less affected by variations in Qs than at the top of the marl or at the surface.

Figures 12 and 13 are comparisons of the ground surface, top of the Cooper Marl, and bottom of the Cooper Marl site amplification spectra for the constant Vs (Figure 12) and gradient Vs (Figure 13) Qs 25 models. Below $1 \mathrm{~Hz}$ for the Top of the Cooper Marl models and below 0.5 
$\mathrm{Hz}$ for the Bottom of the Cooper Marl models, the site amplifications are essentially identical to those at the ground surface. This indicates that low frequency (long period) response is insensitive to the Vs structure shallower than the top or bottom of the marl. But the long-period response (>2s) is more strongly tied to the deeper Vs structure below the marl and the strong Vs contrast at the pre-Cretaceous unconformity.

\section{Comparison (d): Depth of the pre-Cretaceous unconformity}

Figures 14-16 show the effect of the pre-Cretaceous unconformity, and the strong Vs contrast it represents, being at a depth of 1,150 m (3,800 ft) instead of $808 \mathrm{~m}(2,650 \mathrm{ft})$. The upper envelope of relative amplification is not very sensitive to this change in basin depth. The main effect is to shift the locations of the peaks of the rapid variation in relative site response.

This is better seen in Figure 16, which combines Figures 14 and 15 in order to see why the upper envelope should be used as a conservative estimate of site amplification given the model uncertainties. The upper envelope of the site amplification is not particularly sensitive to whether the depth to the bottom of the basin of unconsolidated sediments is just above or just below $1 \mathrm{~km}$ $(3,300 \mathrm{ft})$.

\section{Comparison (e): Vs Contrast at and below the pre-Cretaceous unconformity}

Figures 17 and 18 show the effect of variations in the Vs contrast at the pre-Cretaceous unconformity. Three variations in rock Vs below the pre-Cretaceous unconformity are compared in each figure: $3.6 \mathrm{~km} / \mathrm{s}(11,800 \mathrm{ft} / \mathrm{s})$ representing basalt, $2.9 \mathrm{~km} / \mathrm{s}(9,500 \mathrm{ft} / \mathrm{s})$ representing hard sedimentary rocks, and an unrealistically low Vs of either 1.0 or $2.0 \mathrm{~km} / \mathrm{s}(3,300 \mathrm{or} 6,500 \mathrm{ft} / \mathrm{s})$. Velocities as low as $2.0 \mathrm{~km} / \mathrm{s}$ below the pre-Cretaceous unconformity are geologically improbable. We use them to demonstrate that the rapid variations in relative amplification stem from the velocity contrast at the unconformity. The effect of having lower Vs beneath the preCretaceous unconformity is to lower the site amplification, particularly below $5 \mathrm{~Hz}$. Figures 17 and 18 show that the smaller the contrast, the smaller the amplitudes of the rapid variations. The lowering of site amplification is most pronounced below $2 \mathrm{~Hz}$, indicating how sensitive longperiod response is to the strong Vs contrast at the pre-Cretaceous unconformity.

The four alternatives for layer 8 discussed above, in the subsection on Jurassic and Triassic rocks, do not contribute much to the site amplification at and near the surface, because of low relative velocity contrast between the hard sedimentary rocks $(\mathrm{Vs}=2.9 \mathrm{~km} / \mathrm{s}$, or $9,500 \mathrm{ft} / \mathrm{s}$ ) and the basalts $(\mathrm{Vs}=3.6 \mathrm{~km} / \mathrm{s}$, or 11,800 ft/s). Figures 17 and 18 show the effect of using a rock Vs of $2.9 \mathrm{~km} / \mathrm{s}$ just below the pre-Cretaceous unconformity instead of $3.6 \mathrm{~km} / \mathrm{s}$. This lowers that Vs contrast from a factor of 4.7 to a factor of 3.8 for the model with a constant Vs in layer 7, and from a factor of 2.8 to a factor of 2.2 for the model with a Vs gradient in layer 7 . (The factors of 4.7 and 3.8 are obtained by dividing $0.762 \mathrm{~km} / \mathrm{s}$ in layer 7 into $3.6 \mathrm{~km} / \mathrm{s}$ and $2.9 \mathrm{~km} / \mathrm{s}$, respectively, which represent layer 8 in the constant Vs model. Similarly, the factors of 2.8 and 2.2 are obtained by dividing $1.3 \mathrm{~km} / \mathrm{s}$ at the bottom of layer 7 into $3.6 \mathrm{~km} / \mathrm{s}$ and $2.9 \mathrm{~km} / \mathrm{s}$, respectively, which represent layer 8 in the gradient Vs model.) This slightly reduces the site amplification below $5 \mathrm{~Hz}$. The difference between the rock Vs $=3.6 \mathrm{~km} / \mathrm{s}$ models and the rock $\mathrm{Vs}=2.9 \mathrm{~km} / \mathrm{s}$ models is due to a small reduction of the strong Vs contrast at the pre-Cretaceous unconformity, and not to the still deeper geology and Vs structure between the two unconformities of Table 1.

Figures 19 and 20 show the effect of propagating the rock ground motions up from the basement unconformity at 2,890 m (9,480 ft) and from the bottom of the Cooper Marl instead of

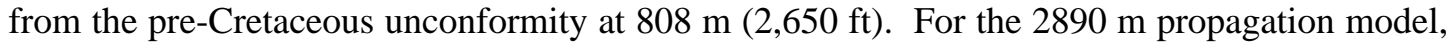


layer 8 was assigned a Vs of $2.9 \mathrm{~km} / \mathrm{s}(9,500 \mathrm{ft} / \mathrm{s})$. For the $808 \mathrm{~m}$ unconformity, both geologically reasonable rock Vs models from Figures 17 and 18 are shown in Figures 19 and 20. We show these two rock Vs models because they are the extremes of the four alternatives for layer 8, with layer 8 being either all hard sedimentary rocks at $2.9 \mathrm{~km} / \mathrm{s}$ or all basalts at $3.6 \mathrm{~km} / \mathrm{s}$ (see "Jurassic and Triassic rocks" above). Notice that there is very little difference in the ground surface amplification among the three unconformity models. This reinforces the fact that the geology between the two unconformities has little impact on site amplification at the bridge site.

The comparison in Figures 19 and 20 with just propagating rock ground motions up from the bottom of the Cooper Marl (the $760 \mathrm{~m} / \mathrm{s}$ or 2,500 ft/s level) again shows the effect of the strong Vs contrast at the pre-Cretaceous unconformity on site amplifications. Simply adjusting NEHRP B/C boundary ground-motion values for the local Vs structure above $100 \mathrm{~m} \mathrm{(330 \textrm {ft } )}$ underestimates the site amplification below $6 \mathrm{~Hz}$.

\section{CONCLUSIONS}

These comparisons show the importance at the Cooper River Bridge site of the strong Vs contrast across the pre-Cretaceous unconformity on long-period site amplification $(\geq 1 \mathrm{~s})$. Merely adjusting the National Seismic Hazard Map (Frankel and others, 1997) ground-motion values from a generic $760 \mathrm{~m} / \mathrm{s}(2,500 \mathrm{ft} / \mathrm{s})$ site condition to a site-specific shallow $(<100 \mathrm{~m}$ or $330 \mathrm{ft}) \mathrm{Vs}$ profile can underestimate the longer period $(>0.5 \mathrm{~s}$ ) site amplification factor by more than a factor of two (Figures 19-20). This is because such an adjustment would not take into account the large Vs contrast at the pre-Cretaceous unconformity. Thus, when long periods $(\geq 1 \mathrm{~s})$ are of engineering concern, it is important to propagate hard-rock ground-motion estimates upward from below such strong, deep contrasts (as was done in the Geomatrix, 2000 report) and not use soft or firm rock estimates and propagate them upward through just the shallow $(<100 \mathrm{~m})$ Vs structure.

As mentioned previously ("Introduction" and "Comparison a..."), our linear analyses are preliminary and are not intended to serve as a basis for design. The analyses are designed to allow SCDOT and the competing firms to decide which additional analyses may be needed, and whether they should collect deep data at the site. For example, earlier we noted the possibility that rocks with Vs less than $2.9 \mathrm{~km} / \mathrm{s}$ might underlie the pre-Cretaceous unconformity (last paragraph in "Jurassic and Triassic rocks"). This possibility should be evaluated with additional modeling of the thicknesses and velocities of such rocks. If the modeling shows that such rocks would significantly alter amplification at periods of interest, then geophysical surveys or deep drilling and velocity-logging could determine whether such rocks exist beneath the site. For another example, a better site-specific estimate than ours would be obtained by propagating a suite of time-histories through a suite of velocity models using an equivalent linear or a non-linear program, such as was done in the Geomatrix, 2000 report for this bridge site. 


\section{REFERENCES CITED}

Ackermann, H. D., 1983, Seismic-refraction study in the area of the Charleston, South Carolina, 1886 earthquake, Chapter F of Gohn, G. S., ed., Studies related to the Charleston, South Carolina, earthquake of 1886 - Tectonics and seismicity: U.S. Geological Survey Professional Paper 1313-F, 20 p.

Behrendt, J. C., Hamilton, R. M., Ackermann, H. D., Henry, V. J., and Bayer, K. C., 1983, Marine multi-channel seismic-reflection evidence for Cenozoic faulting and deep crustal structure near Charleston, South Carolina, Chapter J of Gohn, G. S., ed., Studies related to the Charleston, South Carolina, earthquake of 1886 - Tectonics and seismicity: U.S. Geological Survey Professional Paper 1313-J, 29 p., 3 folded plates.

Bybell, L. M., Conlon, K. J., Edwards, L. E., Frederiksen, N. O., Gohn, G. S., and Self-Trail, J. M., 1983, Biostratigraphy and physical stratigraphy of the USGS-Cannon Park Core (CHN-800), Charleston County, South Carolina: U.S. Geological Survey Open-File Report 98-0246, 65 p.

Campbell, B. G., and Gohn, G. S., 1994, Stratigraphic framework for geologic and geohydrologic studies of the subsurface Cretaceous section near Charleston, South Carolina: U.S. Geological Survey Miscellaneous Field Studies Map MF-2273, 2 folded sheets, 11 p. pamphlet.

Chapman, M. C., Bollinger, G. A., Sibol, M. S., and Stephenson, D. E., 1990, The influence of the Coastal Plain sedimentary wedge on strong ground motions from the 1886 Charleston, South Carolina, earthquake: Earthquake Spectra, v. 6, p. 617-640.

Chen, K.-C., Chiu, J.-M., and Yang, Y.-T., 1994, Qp-Qs relations in the sedimentary basin of the upper Mississippi embayment using converted phases: Bulletin of the Seismological Society of America, v. 84, p. 1861-1868.

Chowns, T. M., and Williams, C. T., 1983, Pre-Cretaceous rocks beneath the Georgia Coastal Plain - Regional implications, Chapter L of Gohn, G. S., ed., Studies related to the Charleston, South Carolina, earthquake of 1886 - Tectonics and seismicity: U.S. Geological Survey Professional Paper 1313-L, 42 p., 1 folded plate.

Daniels, D. L., Zietz, I., and Popenoe, P., 1983, Distribution of subsurface Lower Mesozoic rocks in the southeastern United States, as interpreted from regional aeromagnetic and gravity maps, Chapter K of Gohn, G. S., ed., Studies related to the Charleston, South Carolina, earthquake of 1886 - Tectonics and seismicity: U.S. Geological Survey Professional Paper 1313-K, 24 p., 1 folded plate.

Frankel, Arthur, Mueller, Charles, Barnhard, Theodore, Perkins, David, Leyendecker, E.V., Dickman, Nancy, Hanson, Stanley, and Hopper, Margaret, 1997, Seismic-hazard maps for the conterminous United States: U.S. Geological Survey Open-File Report 97-131, 12 sheets, scale 1:7,000,000.

Geomatrix, 2000, Final report Cooper River bridges replacement project ground motion hazard analysis: Geomatrix Consultants, Inc., Project No. 5368, 62 p. 
Gohn, G. S., 1988, Late Mesozoic and early Cenozoic geology of the Atlantic Coastal Plain North Carolina to Florida, in Sheridan, R. E., and Grow, J. A., eds., The Geology of North America, v. I-2, The Atlantic Continental Margin, U.S.: Boulder, Colorado, Geological Society of America, p. 107-130.

Gohn, G. S., Higgins, B. B., Smith, C. S., and Owens, J. P., 1977, Lithostratigraphy of the deep corehole (Clubhouse Crossroads corehole 1) near Charleston, South Carolina, Chapter E of Rankin, D. W., ed., Studies related to the Charleston, South Carolina, earthquake of 1886 - A preliminary report: U.S. Geological Survey Professional Paper 1028-E, p. 5970.

Gohn, G. S., Houser, B. B., and Schneider, R. R., 1983, Geology of the lower Mesozoic(?) sedimentary rocks in Clubhouse Crossroads test hole \#3, near Charleston, South Carolina, Chapter A of Gohn, G. S., ed., Studies related to the Charleston, South Carolina, earthquake of 1886 - Tectonics and seismicity: U.S. Geological Survey Professional Paper 1313-A, 19 p.

Gottfried, D., Annell, C. S., and Byerly, G. R., 1983, Geochemistry and tectonic significance of subsurface basalts near Charleston, South Carolina - Clubhouse Crossroads test holes \#2 and \#3, Chapter D of Gohn, G. S., ed., Studies related to the Charleston, South Carolina, earthquake of 1886 - Tectonics and seismicity: U.S. Geological Survey Professional Paper 1313-D, 17 p.

Hamilton, R. M., Behrendt, J. C., and Ackermann, H. D., 1983, Land multichannel seismicreflection evidence for tectonic features near Charleston, South Carolina, Chapter I of Gohn, G. S., ed., Studies related to the Charleston, South Carolina, earthquake of 1886 Tectonics and seismicity: U.S. Geological Survey Professional Paper 1313-I, 18 p., 1 folded plate.

Mueller, C. S., submitted, Site response in the Atlantic and Gulf of Mexico Coastal Plain and Mississippi embayment: Sixth International Conference on Seismic Zonation, Palm Springs, California, November 12-15, 2000, 6 ms. p.

Schilt, F. S., Brown, L. D., Oliver, J. E., and Kaufman, S., 1983, Subsurface structure near Charleston, South Carolina - Results of COCORP reflection profiling in the Atlantic Coastal Plain, Chapter H of Gohn, G. S., ed., Studies related to the Charleston, South Carolina, earthquake of 1886 - Tectonics and seismicity: U.S. Geological Survey Professional Paper 1313-H, 19 p.

Schnabel, P. B., Lysmer, J., and Seed, H.B., 1972, SHAKE, a computer program for earthquake response analysis of horizontally layered sites: Earthquake Engineering Research Center, University of California, Report No. EERC 72-12.

Talwani, P., 1977, A preliminary shallow crustal model between Columbia and Charleston, South Carolina, determined from quarry blast monitoring and other geophysical data, Chapter M of Rankin, D. W., ed., Studies related to the Charleston, South Carolina, earthquake of 1886 - A preliminary report: U.S. Geological Survey Professional Paper 1028-M, p. 177187.

Yantis, B. R., Costain, J. K., and Ackermann, H. D., 1983, A reflection seismic study near Charleston, South Carolina, Chapter G of Gohn, G. S., ed., Studies related to the 
Charleston, South Carolina, earthquake of 1886 - Tectonics and seismicity: U.S. Geological Survey Professional Paper 1313-G, 20 p. 


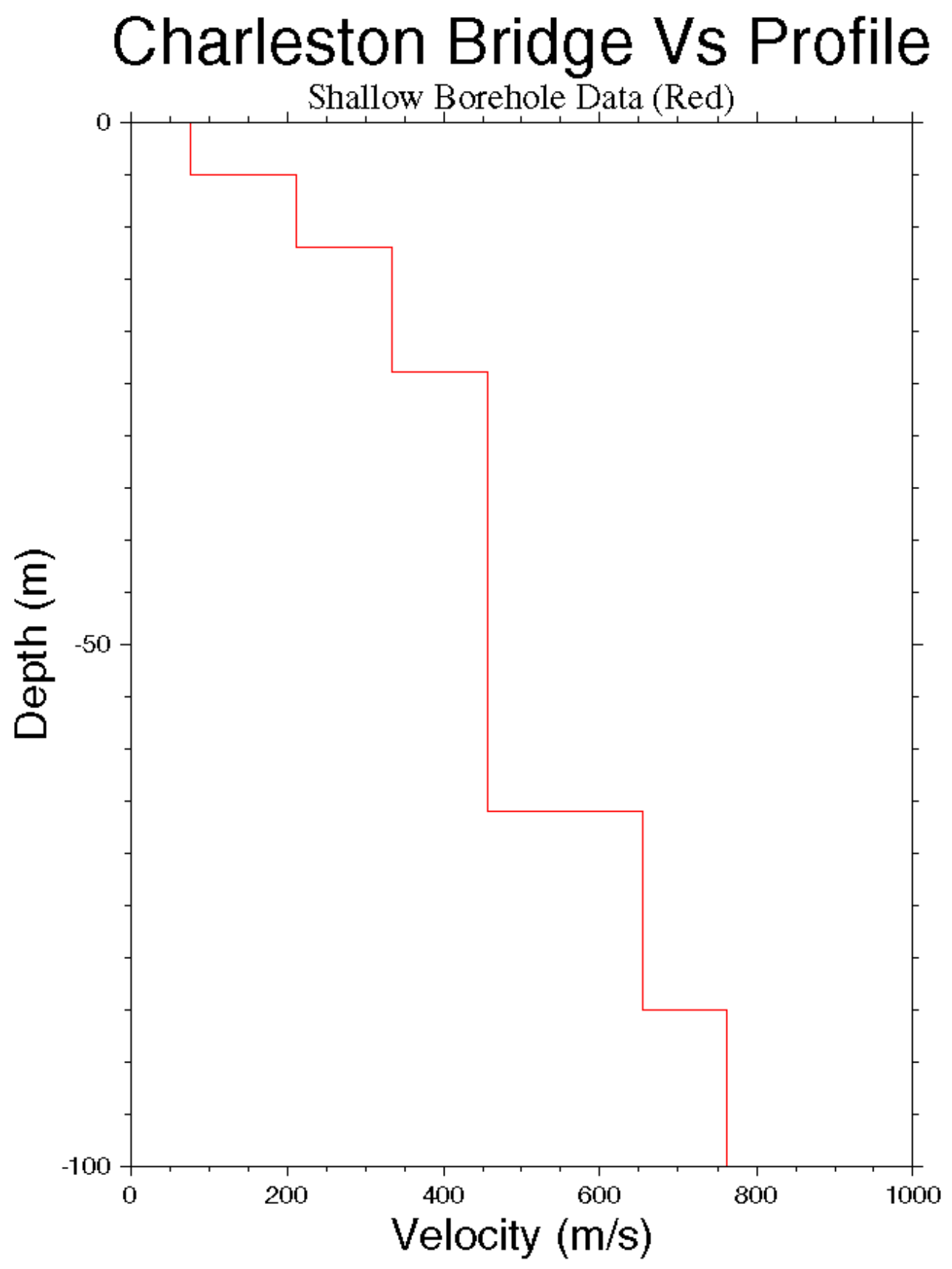

Figure 1. Shallow bridge-site Vs profile interpreted from measurements by Redpath Geophysics in borehole DS-1 (Table 1). 


\section{Charleston, SC Vs Profiles}

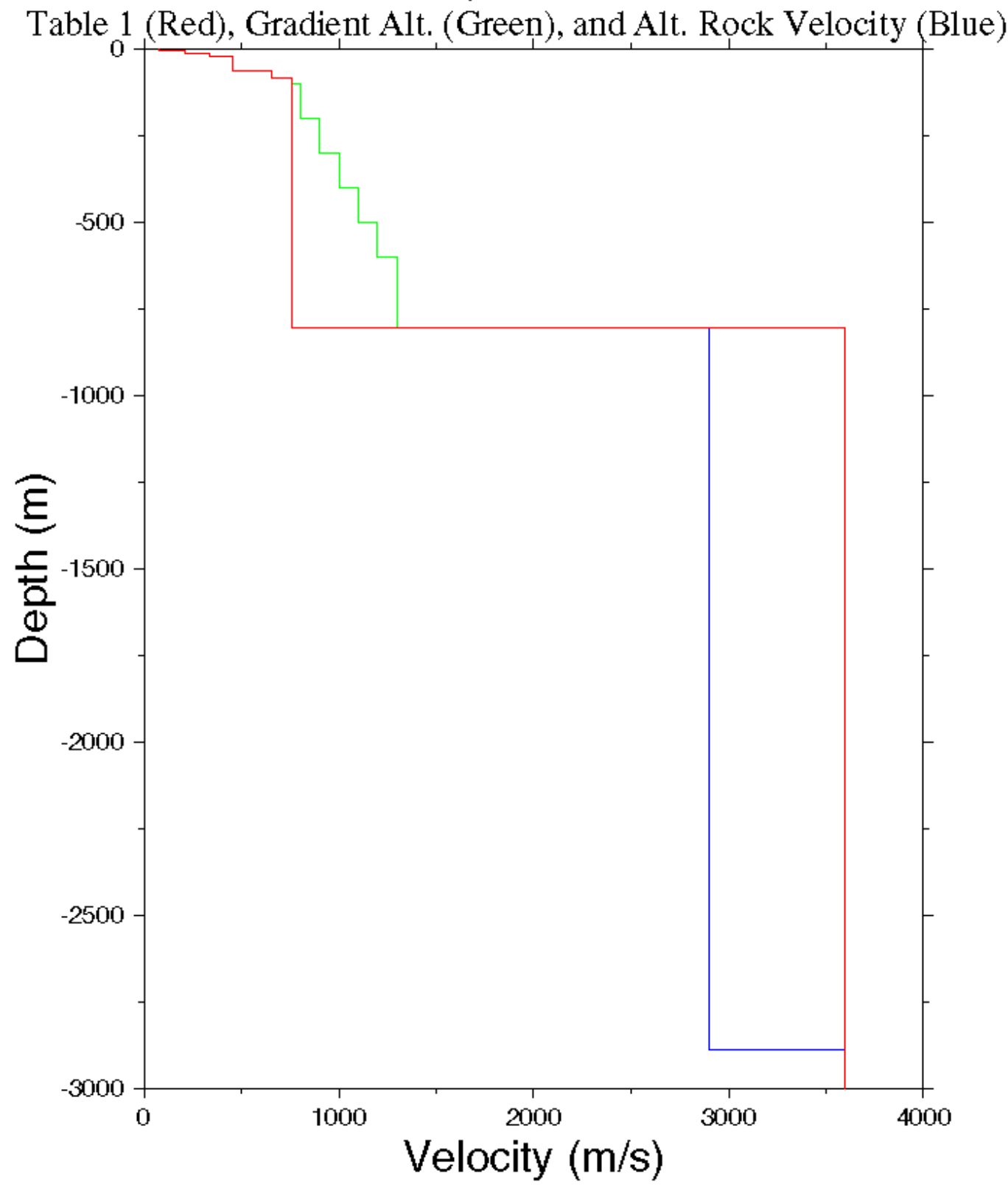

Figure 2. Full bridge-site Vs profile from Table 1, including alternative interpretations (see text). 


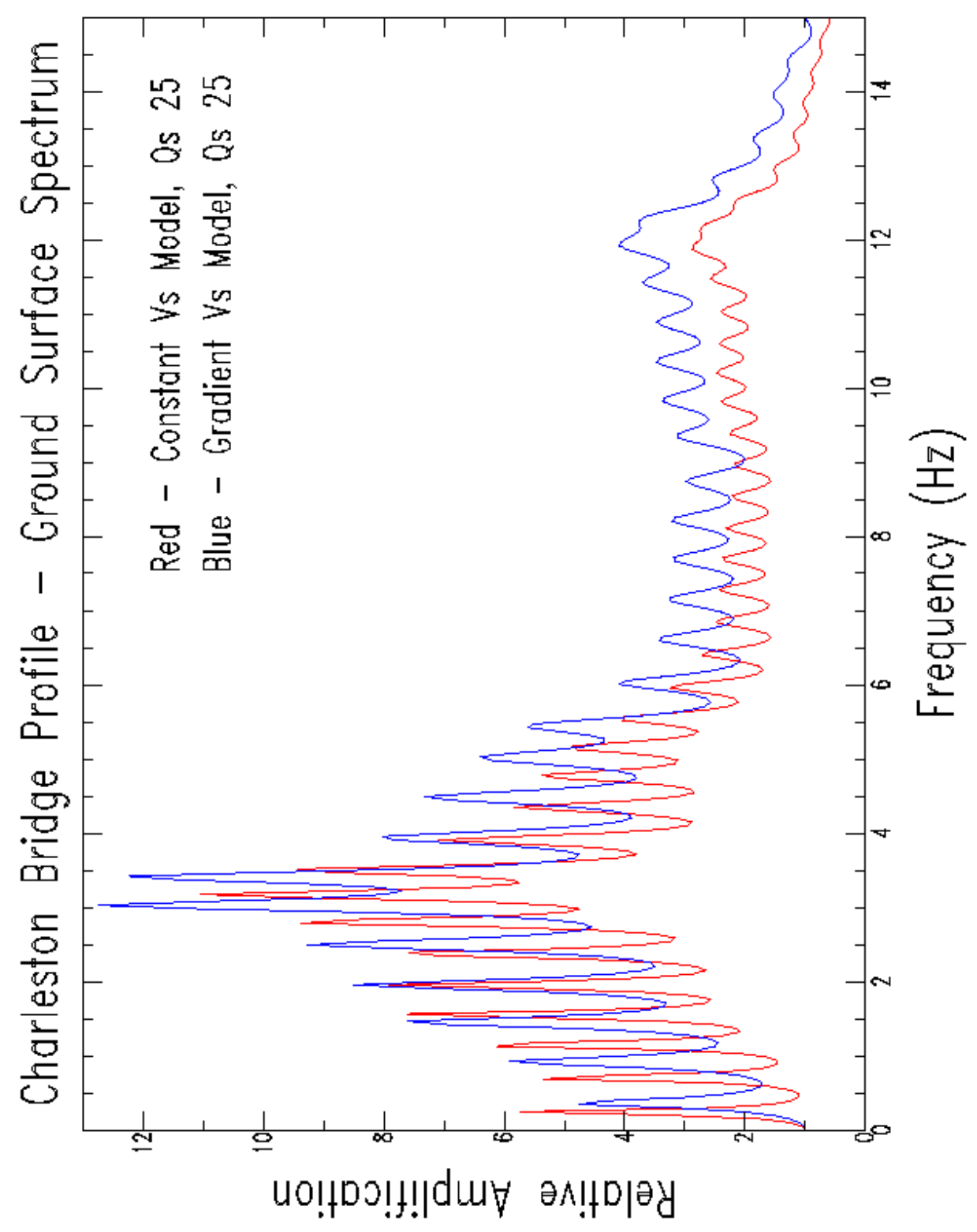

Figure 3. Relative amplification spectrum at the ground surface for profiles with the constant and gradient Vs alternatives for layer 7 of Table 1 and Figure 2. Qs $=25$ in layers 1-3. 


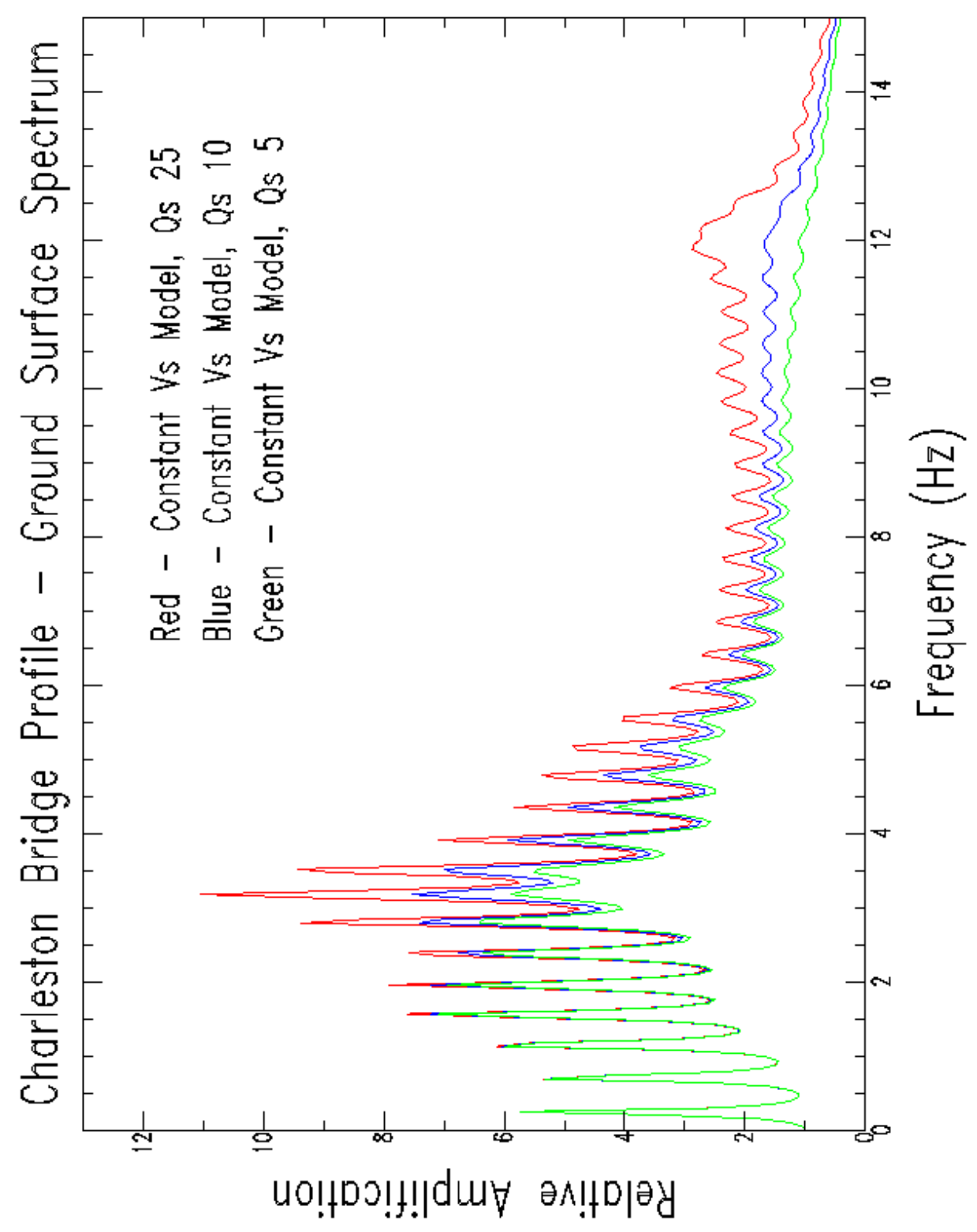

Figure 4. Comparison of relative amplification spectrum at the ground surface for models with a constant Vs in layer 7 and with Qs $=25$ in layers 1-3, Qs $=10$ in layers 1-3, and Qs $=5$ in layer 1 and $\mathrm{Qs}=10$ in layers 2-3. The curve for $\mathrm{Qs}=25$ is from Figure 3. 


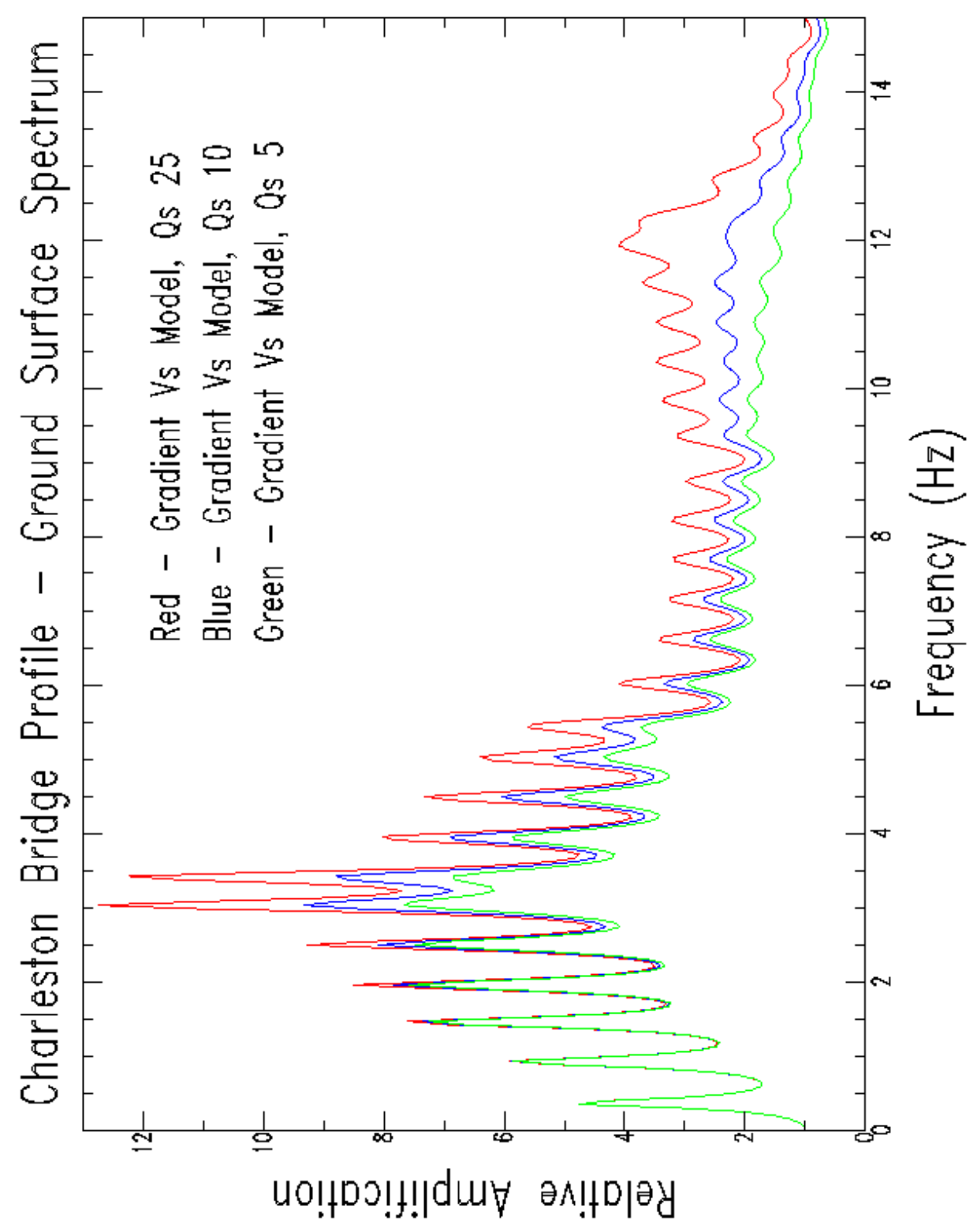

Figure 5. Comparison of relative amplification spectrum at the ground surface for models with a gradient Vs in layer 7 and with Qs $=25$ in layers $1-3$, Qs $=10$ in layers 1-3, and Qs $=5$ in layer 1 and $\mathrm{Qs}=10$ in layers 2-3. The curve for Qs $=25$ is from Figure 3. 


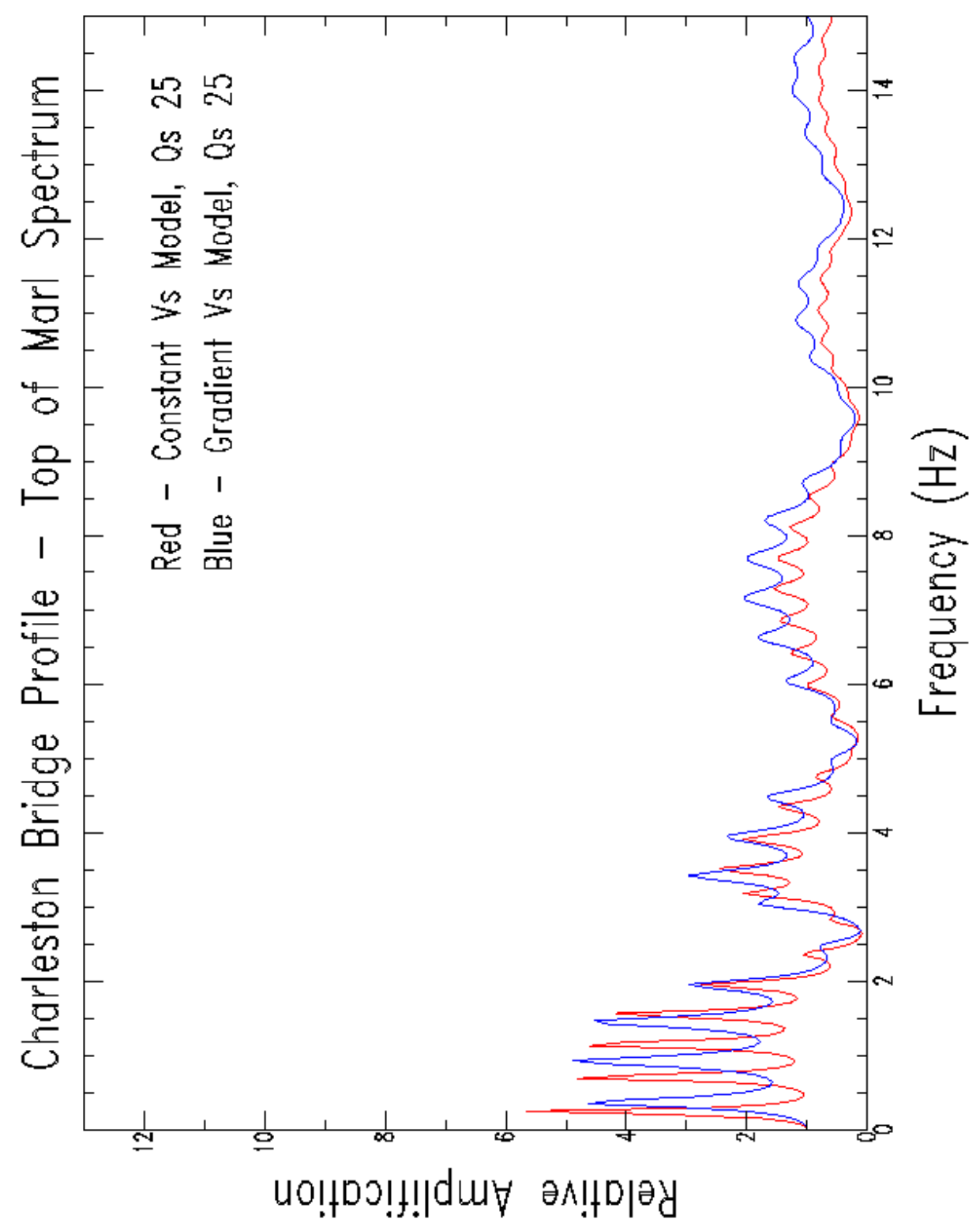

Figure 6. Relative amplification spectrum at the top of the Cooper Marl for models of Figure 3. 


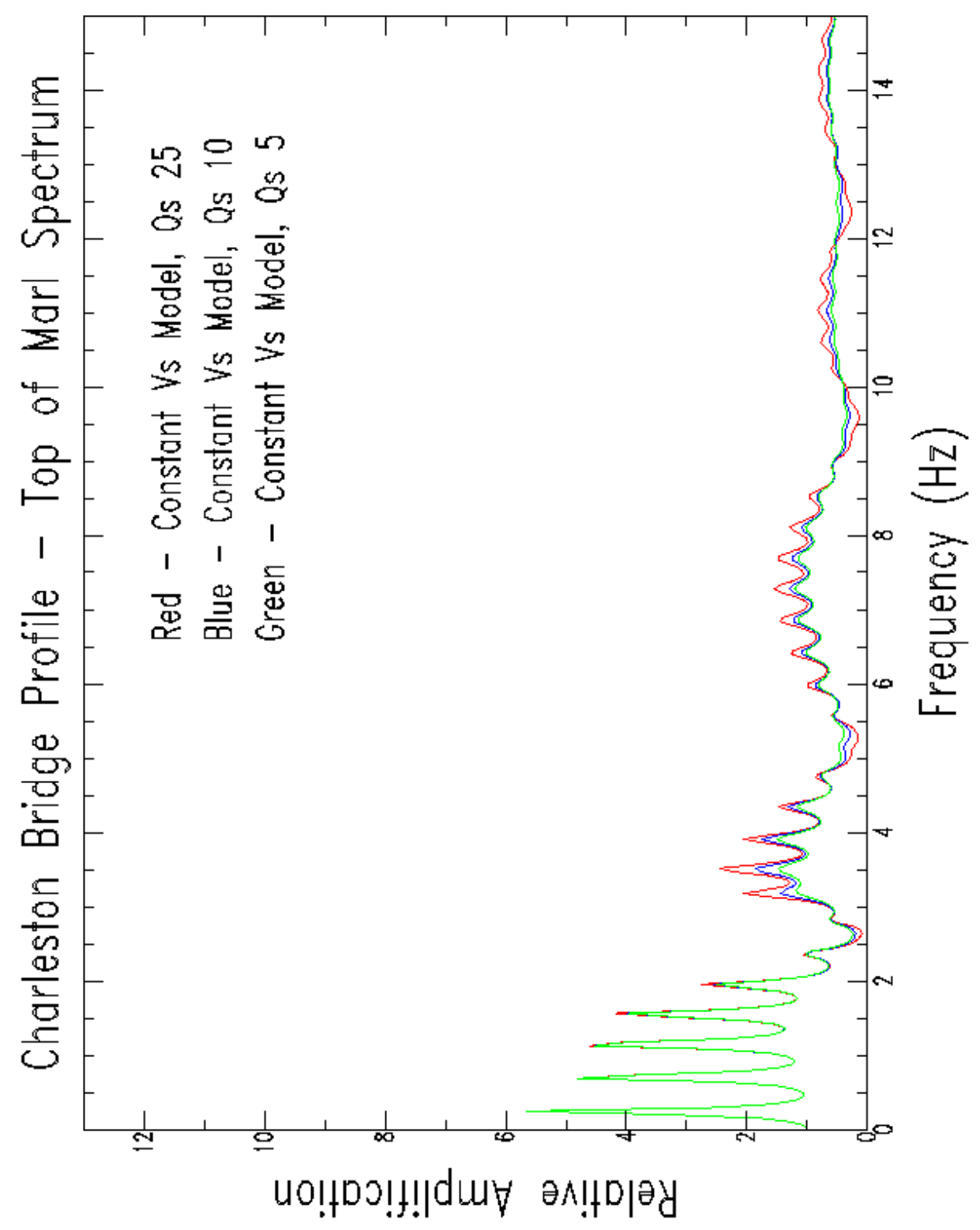

Figure 7. Comparison of relative amplification spectrum at the top of the Cooper Marl for models with Qs $=25$ in layers 1-3, Qs $=10$ in layers $1-3$, and Qs $=5$ in layer 1 and Qs $=10$ in layers 2-3, as done in Figure 4. The curve for Qs $=25$ is from Figure 6. 


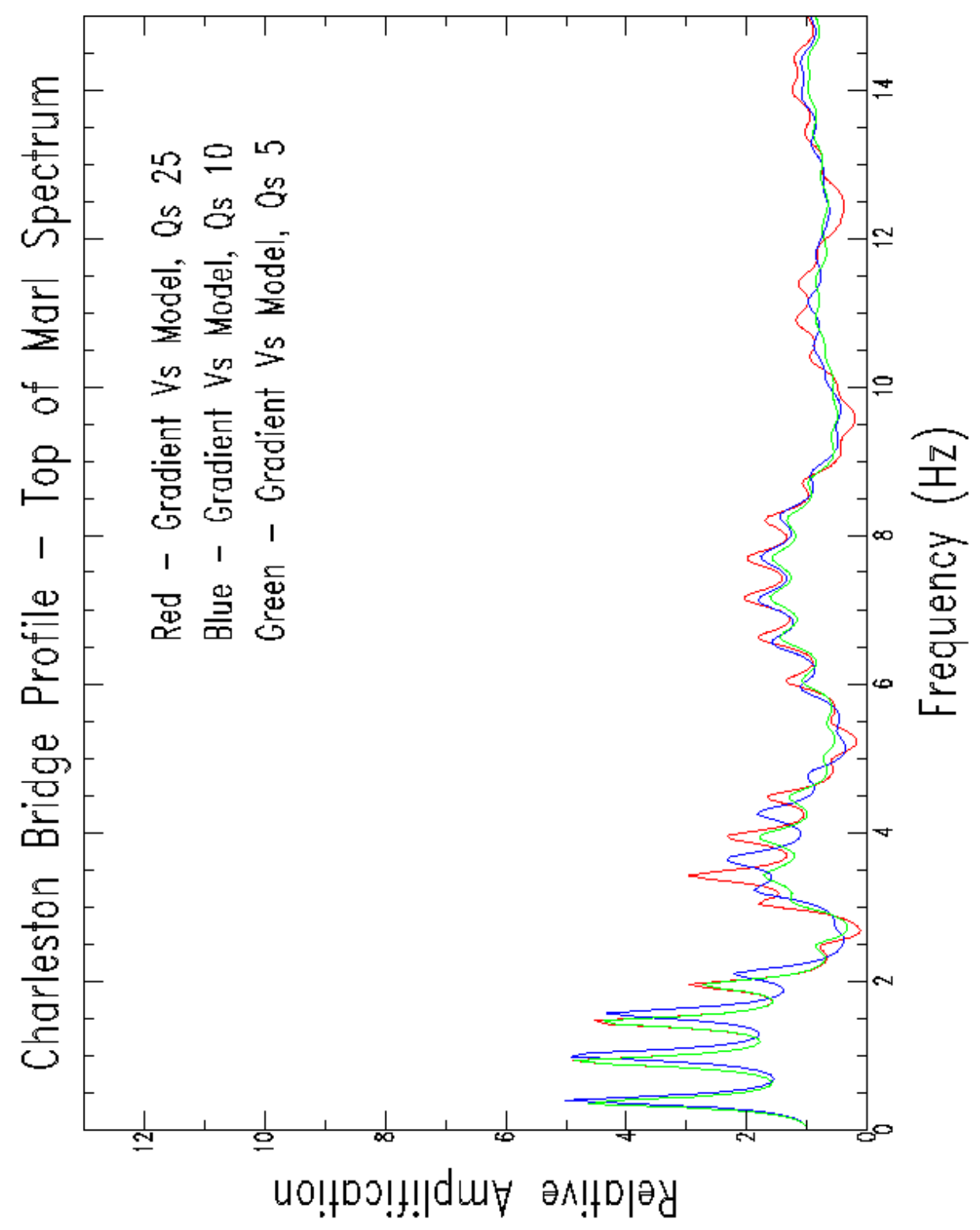

Figure 8. Comparison of relative amplification spectrum at the top of the Cooper Marl for models with Qs $=25$ in layers 1-3, Qs $=10$ in layers 1-3, and Qs $=5$ in layer 1 and Qs $=10$ in layers 2-3, as done in Figure 5. The curve for Qs $=25$ is from Figure 6. 


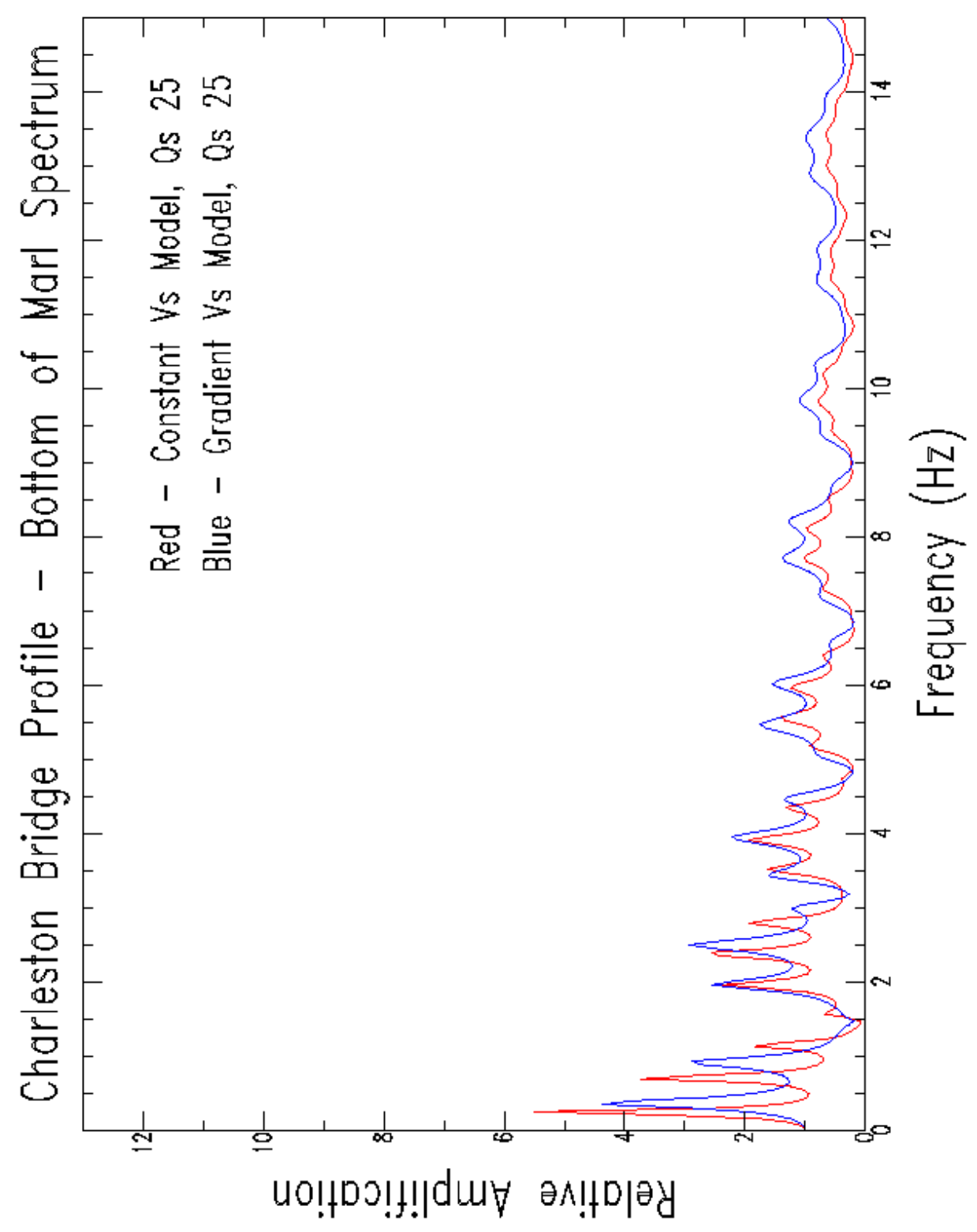

Figure 9. Relative amplification spectrum at the bottom of the Cooper Marl for models of Figure 3. 


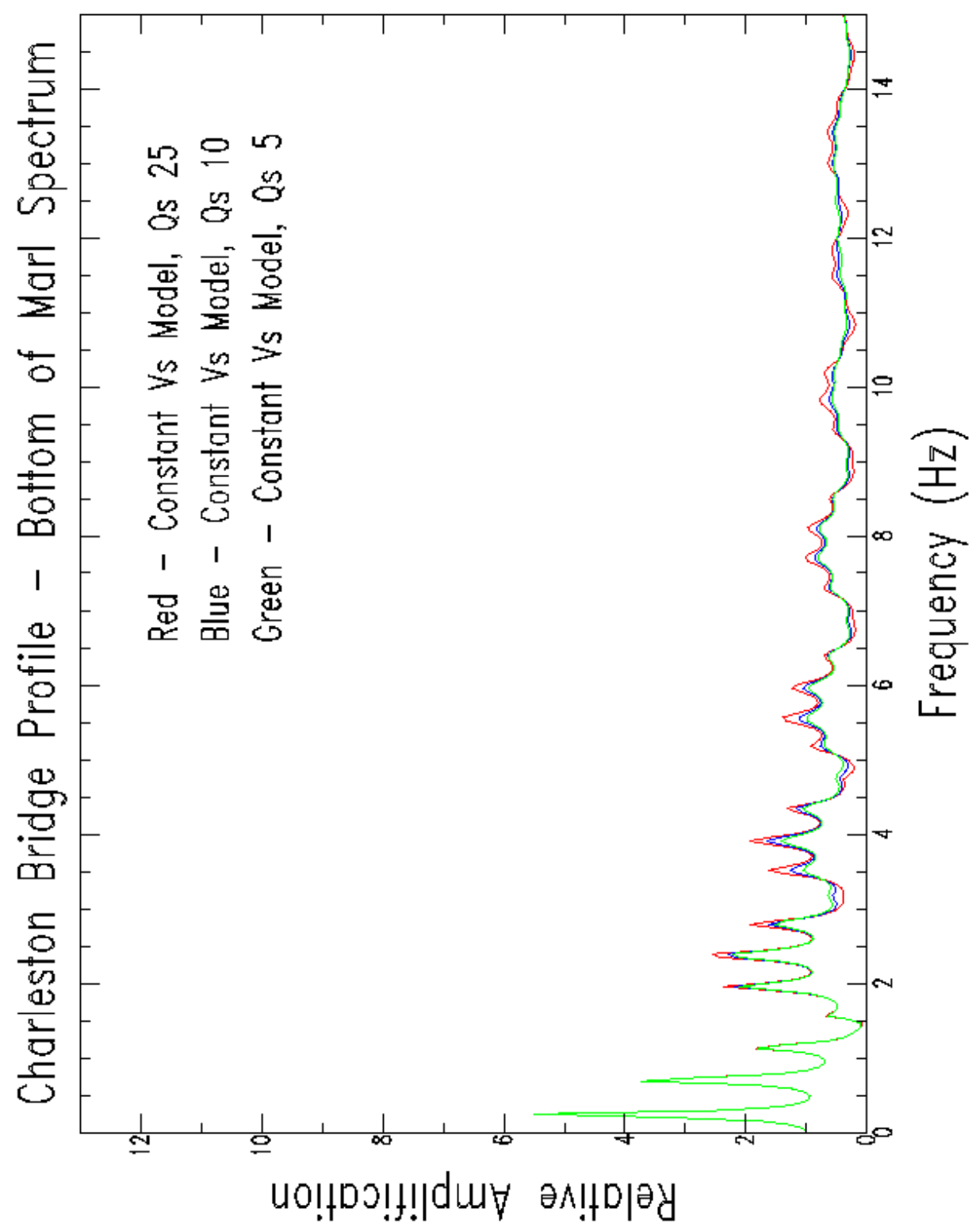

Figure 10. Comparison of relative amplification spectrum at the bottom of the Cooper Marl for models with Qs $=25$ in layers 1-3, Qs $=10$ in layers $1-3$, and Qs $=5$ in layer 1 and Qs $=10$ in layers 2-3, as done in Figure 4. The curve for $\mathrm{Qs}=25$ is from Figure 9. 


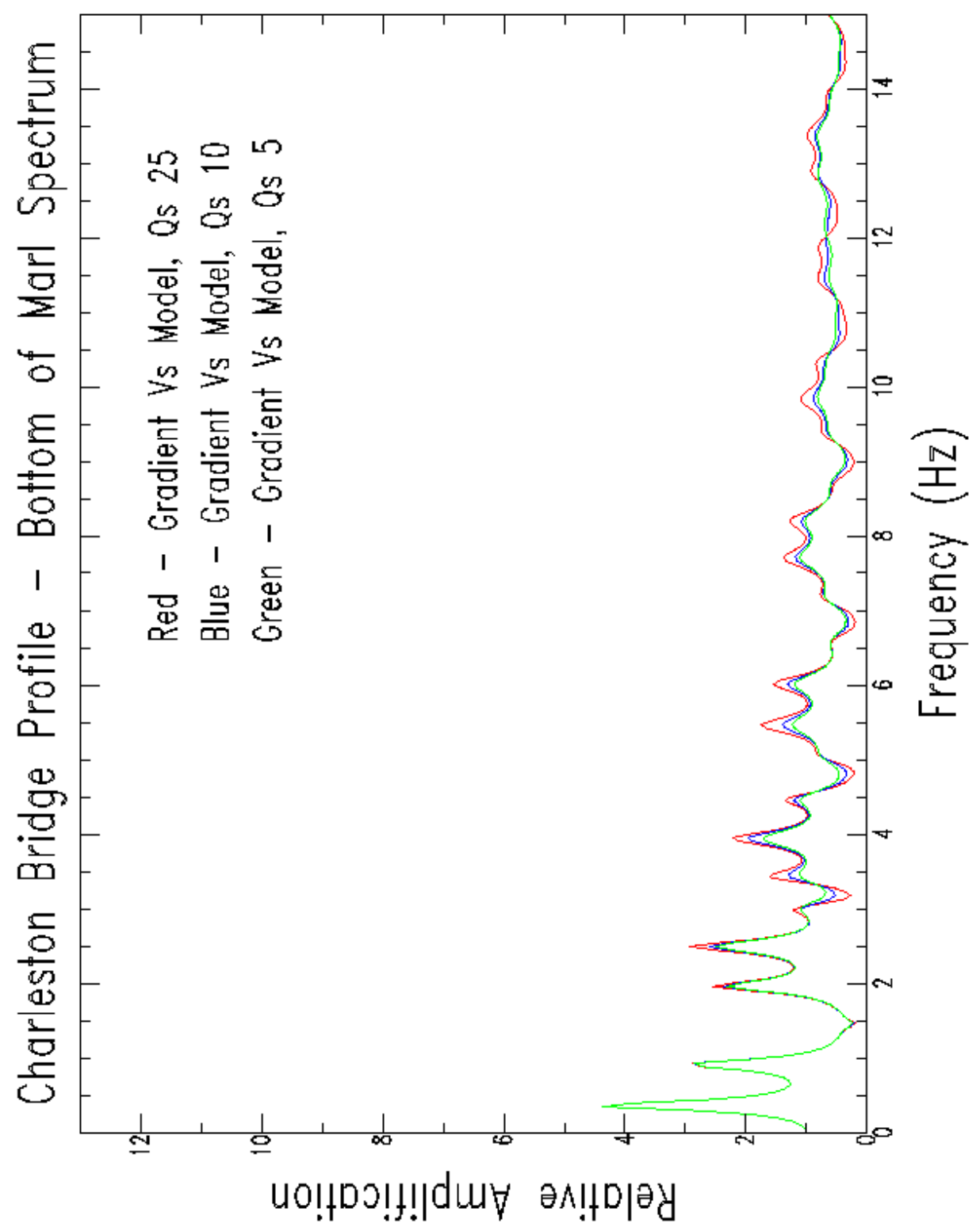

Figure 11. Comparison of relative amplification spectrum at the bottom of the Cooper Marl for models with Qs $=25$ in layers 1-3, Qs $=10$ in layers $1-3$, and Qs $=5$ in layer 1 and Qs $=10$ in layers 2-3, as done in Figure 5. The curve for $\mathrm{Qs}=25$ is from Figure 9. 


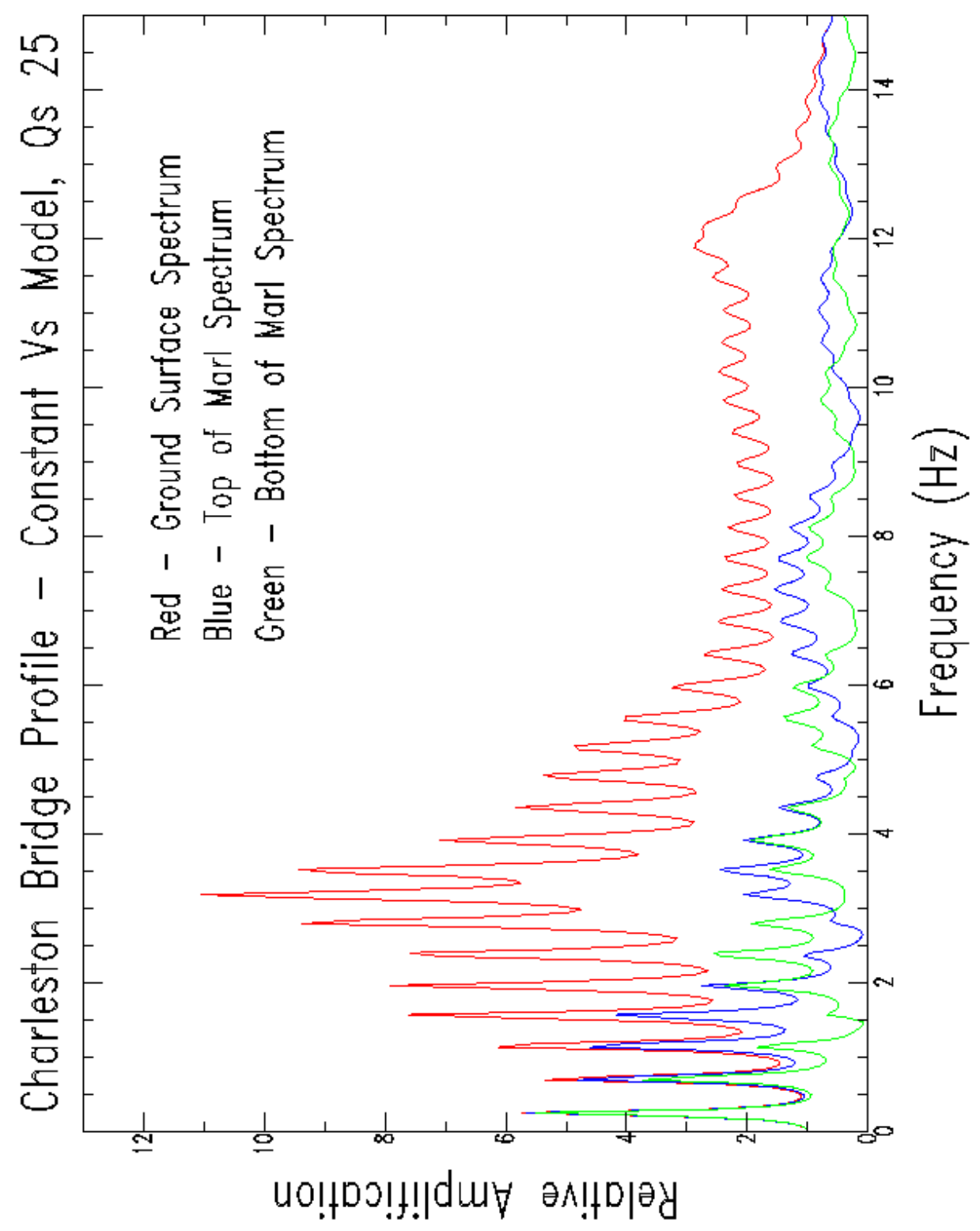

Figure 12. Comparison of relative amplification spectrum as observed at the ground surface and at the top and bottom of the Cooper Marl, for models with a constant Vs in layer 7 and with a Qs of 25 in layers 1-3. The curves are from Figures 3, 6, and 9. 


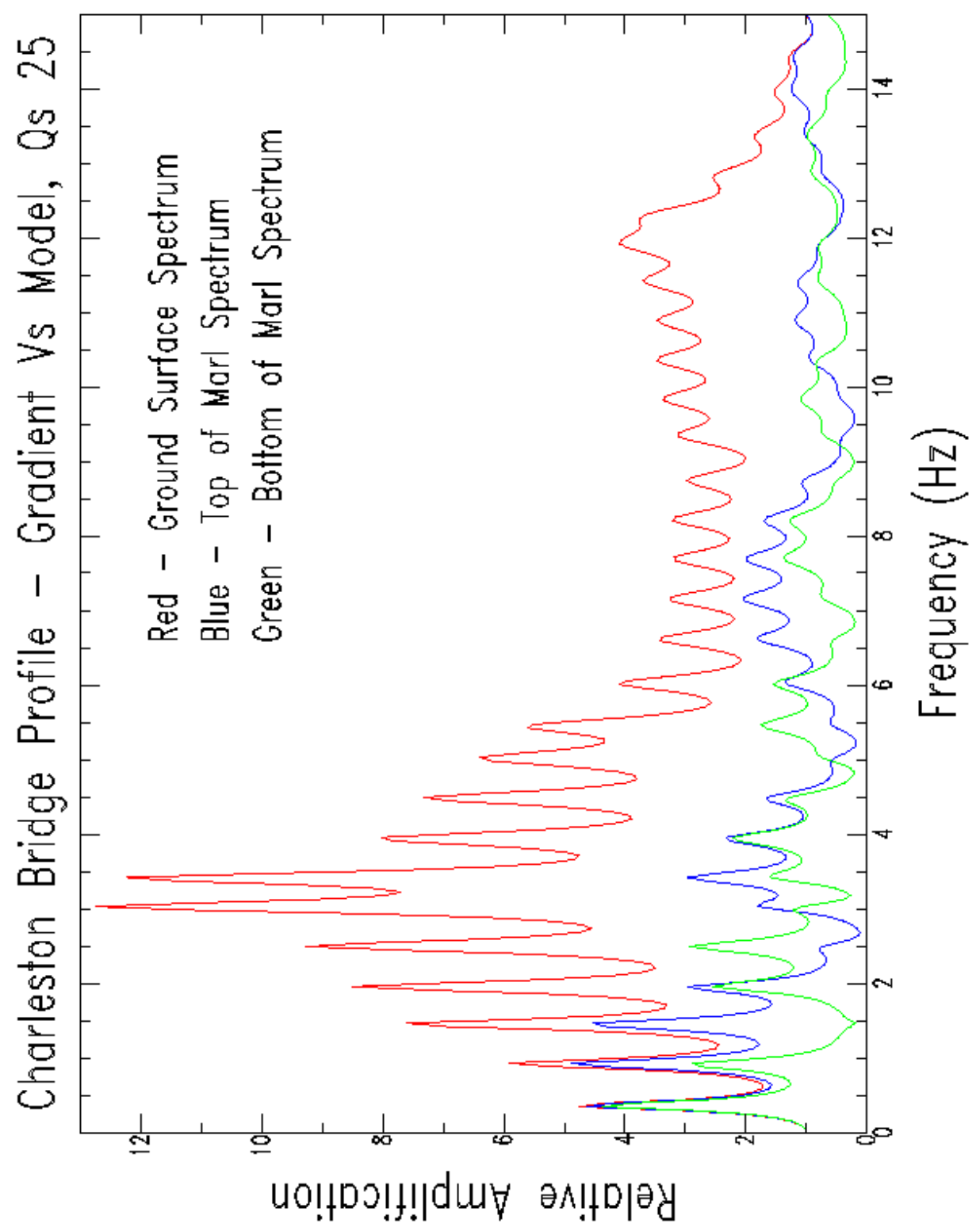

Figure 13. Comparison of relative amplification spectrum as observed at the ground surface and at the top and bottom of the Cooper Marl, for models with a gradient Vs in layer 7 and with a Qs of 25 in layers 1-3. The curves are from Figures 3, 6, and 9. 


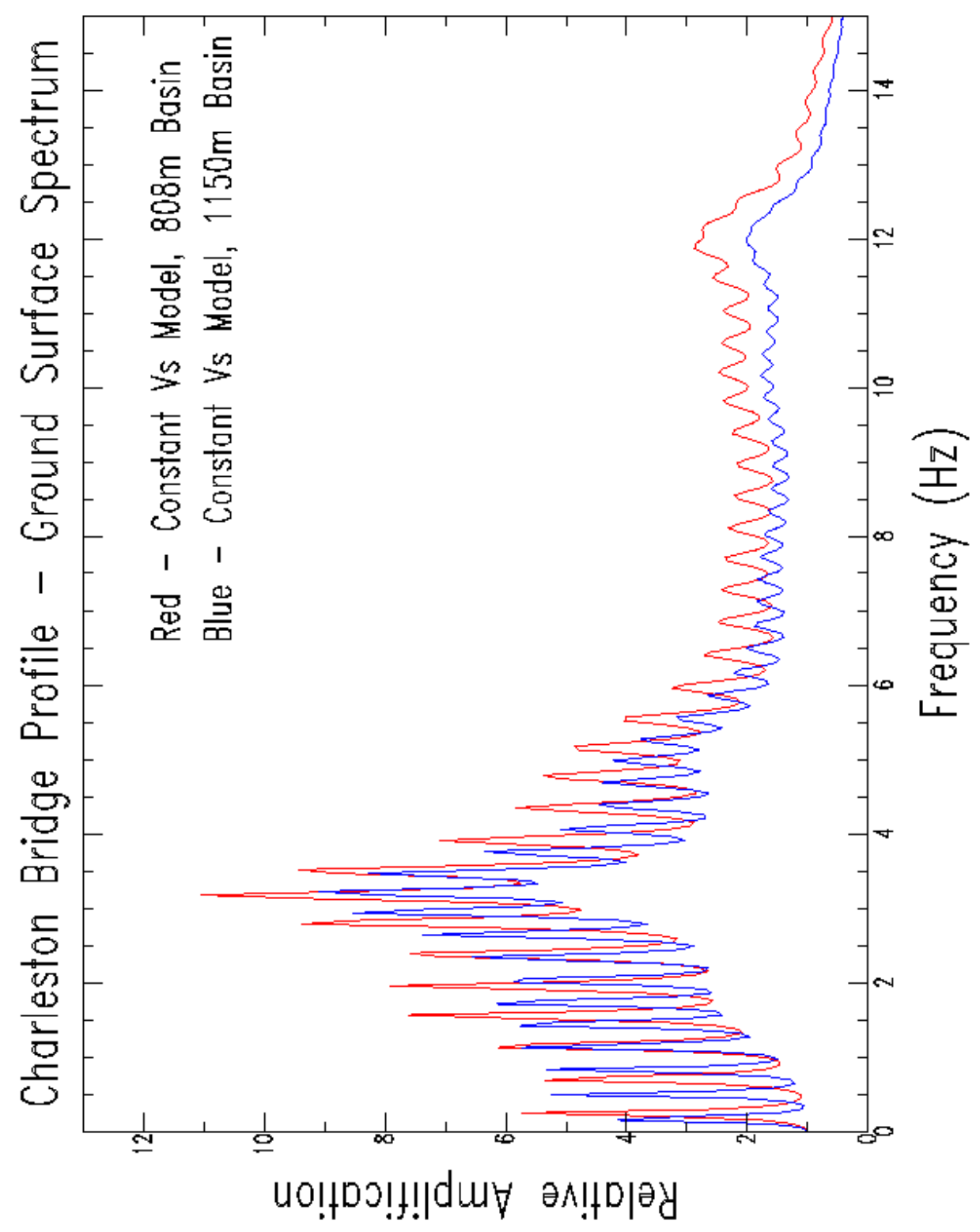

Figure 14. Comparison of relative amplification spectrum at the ground surface for models with a constant Vs in layer 7 and with a $1,150 \mathrm{~m}(3,800 \mathrm{ft})$ and $808 \mathrm{~m}(2,650 \mathrm{ft})$ depth to the pre-

Cretaceous unconformity. Qs $=25$ in layers 1-3. The curve for $808 \mathrm{~m}$ depth is from Figure 3. 


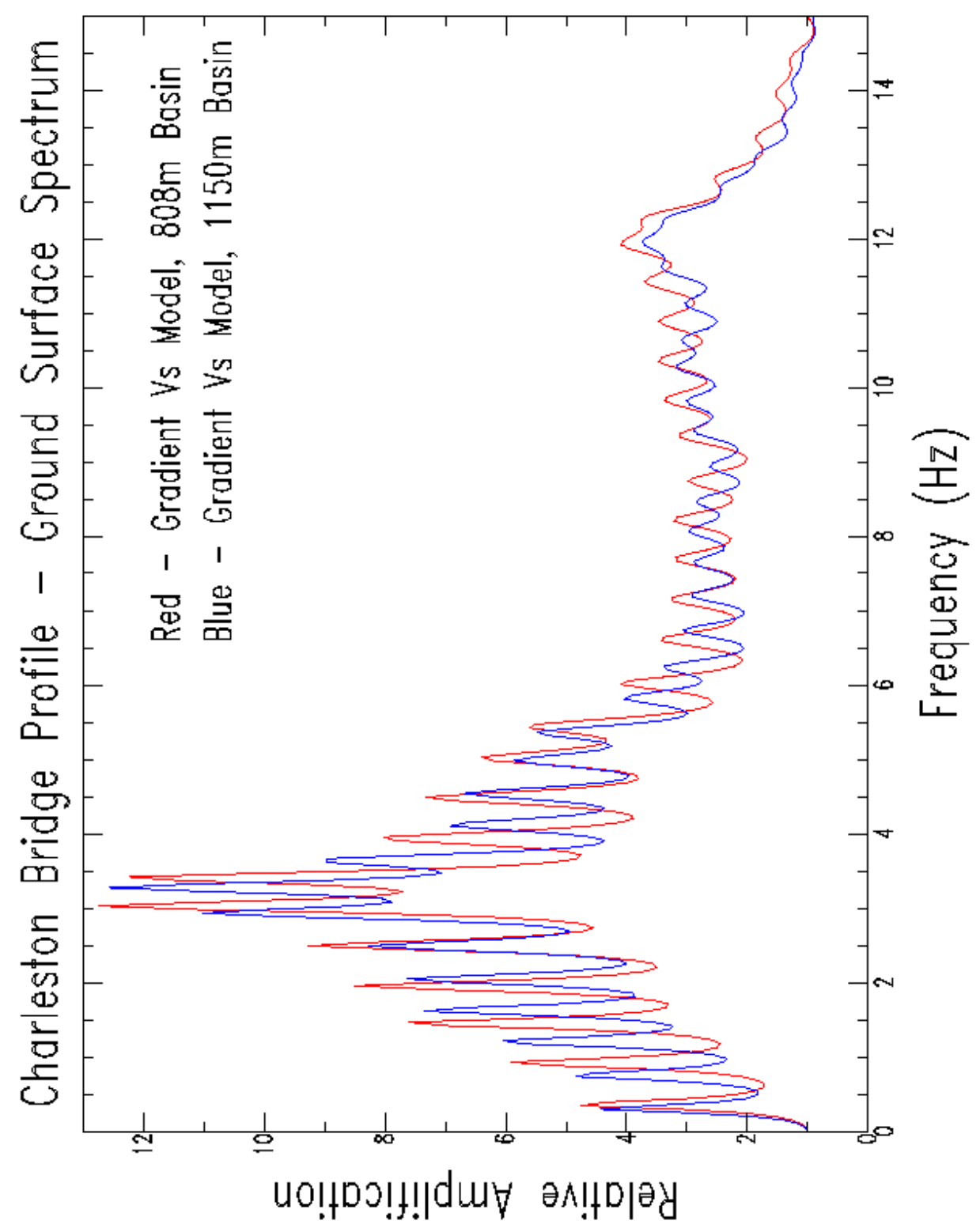

Figure 15. Comparison of relative amplification spectrum at the ground surface for models with a gradient Vs in layer 7 and with a $1,150 \mathrm{~m}(3,800 \mathrm{ft})$ and $808 \mathrm{~m}(2,650 \mathrm{ft})$ depth to the pre-

Cretaceous unconformity. Qs $=25$ in layers 1-3. The curve for $808 \mathrm{~m}$ depth is from Figure 3. 


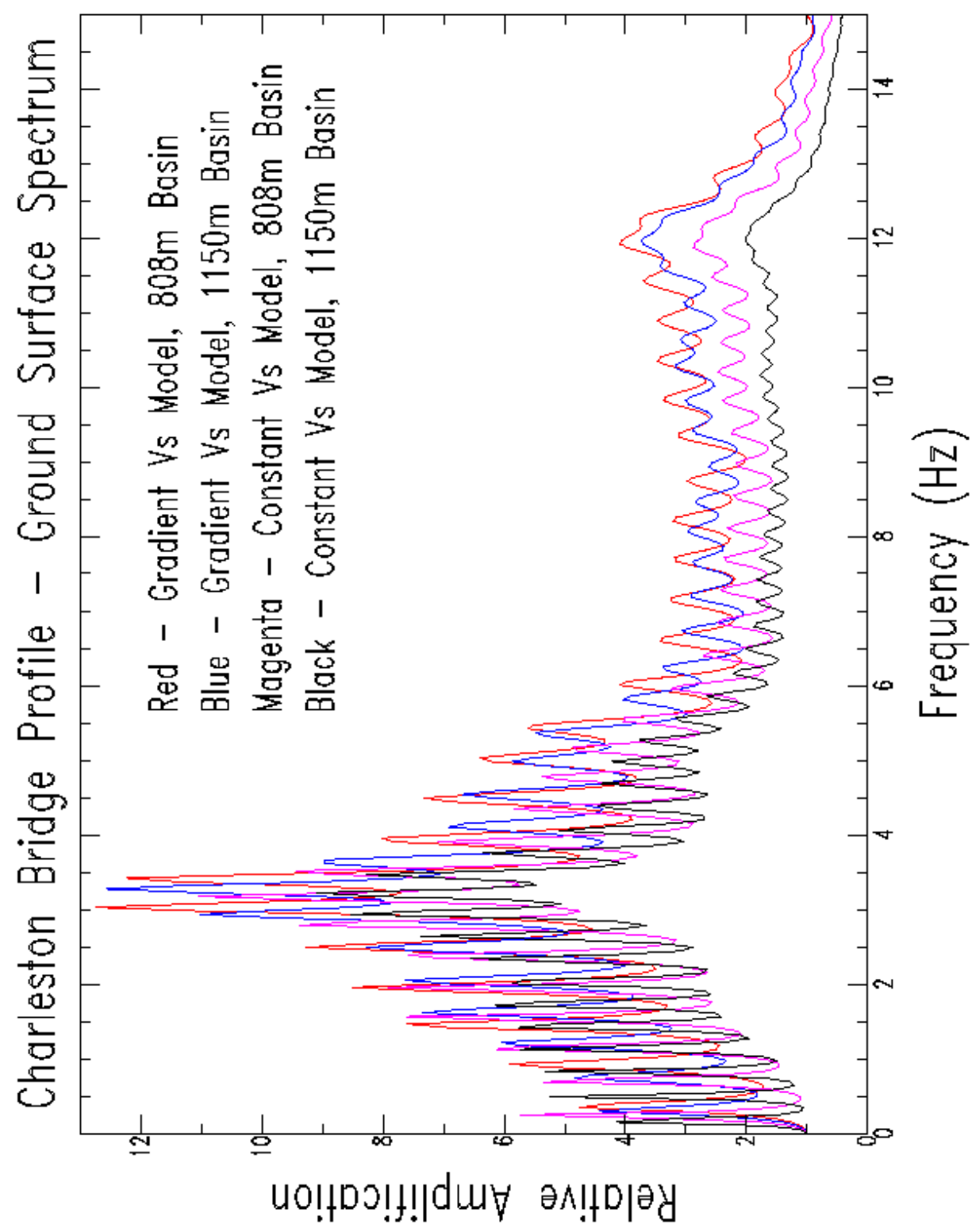

Figure 16. Comparison of relative amplification spectrum at the ground surface for the models of both Figures 14 and 15. 


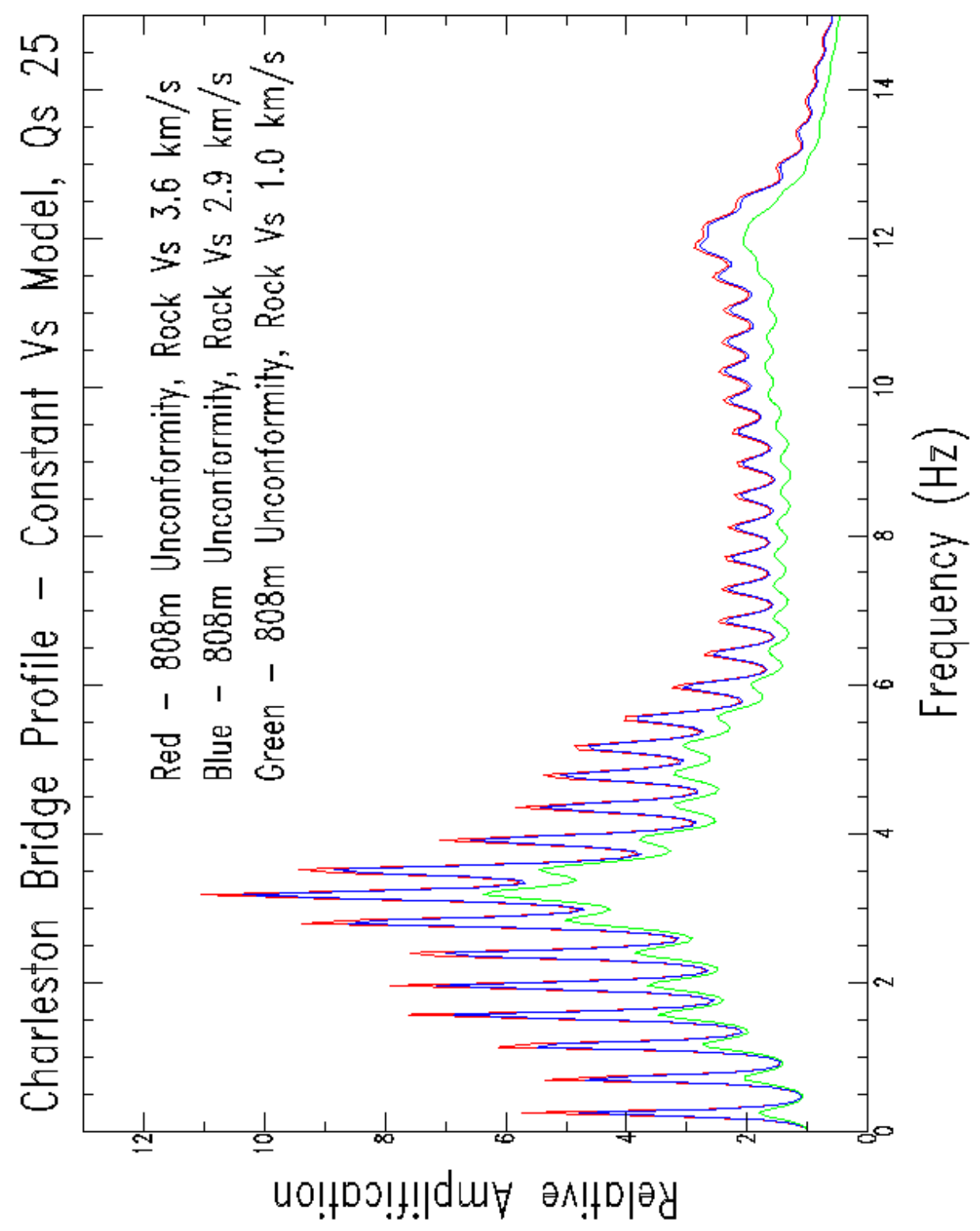

Figure 17. Comparison of relative amplification spectrum at the ground surface for models with a constant Vs in layer 7 and with rock Vs equal to $3.6 \mathrm{~km} / \mathrm{s}(11,800 \mathrm{ft} / \mathrm{s}), 2.9 \mathrm{~km} / \mathrm{s}(9,500 \mathrm{ft} / \mathrm{s})$ and $1.0 \mathrm{~km} / \mathrm{s}(3,300 \mathrm{ft} / \mathrm{s})$ for layer 8 of Table 1 . The curve for $3.6 \mathrm{~km} / \mathrm{s}$ is from Figure 3. Qs $=25$ in layers $1-3$. 


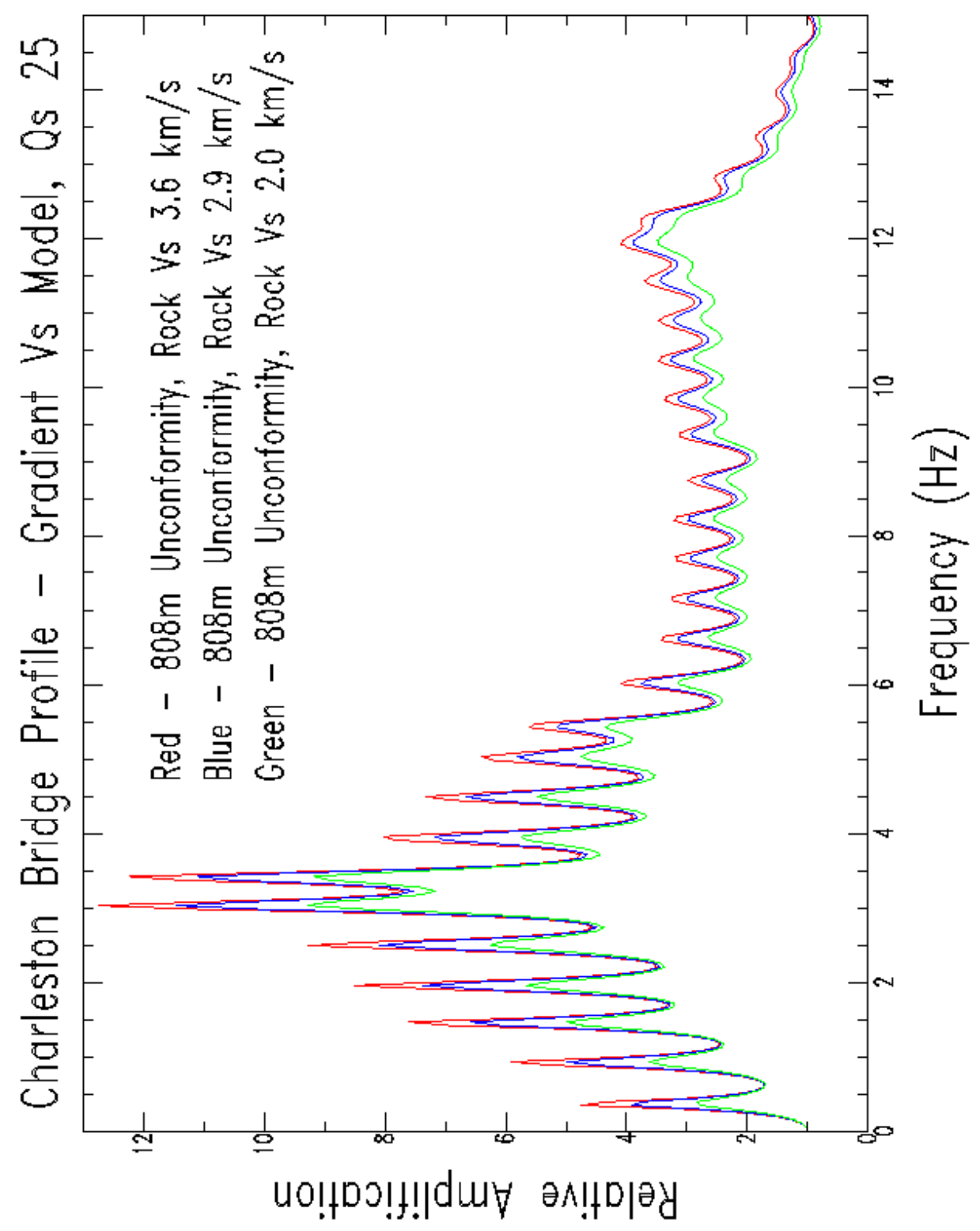

Figure 18. Comparison of relative amplification spectrum at the ground surface for models with a gradient Vs in layer 7 and with rock Vs equal to $3.6 \mathrm{~km} / \mathrm{s}(11,800 \mathrm{ft} / \mathrm{s}), 2.9 \mathrm{~km} / \mathrm{s}(9,500 \mathrm{ft} / \mathrm{s})$ and $2.0 \mathrm{~km} / \mathrm{s}(6,500 \mathrm{ft} / \mathrm{s})$ for layer 8 of Table 1 . The curve for $3.6 \mathrm{~km} / \mathrm{s}$ is from Figure 3. Qs $=25 \mathrm{in}$ layers $1-3$. 


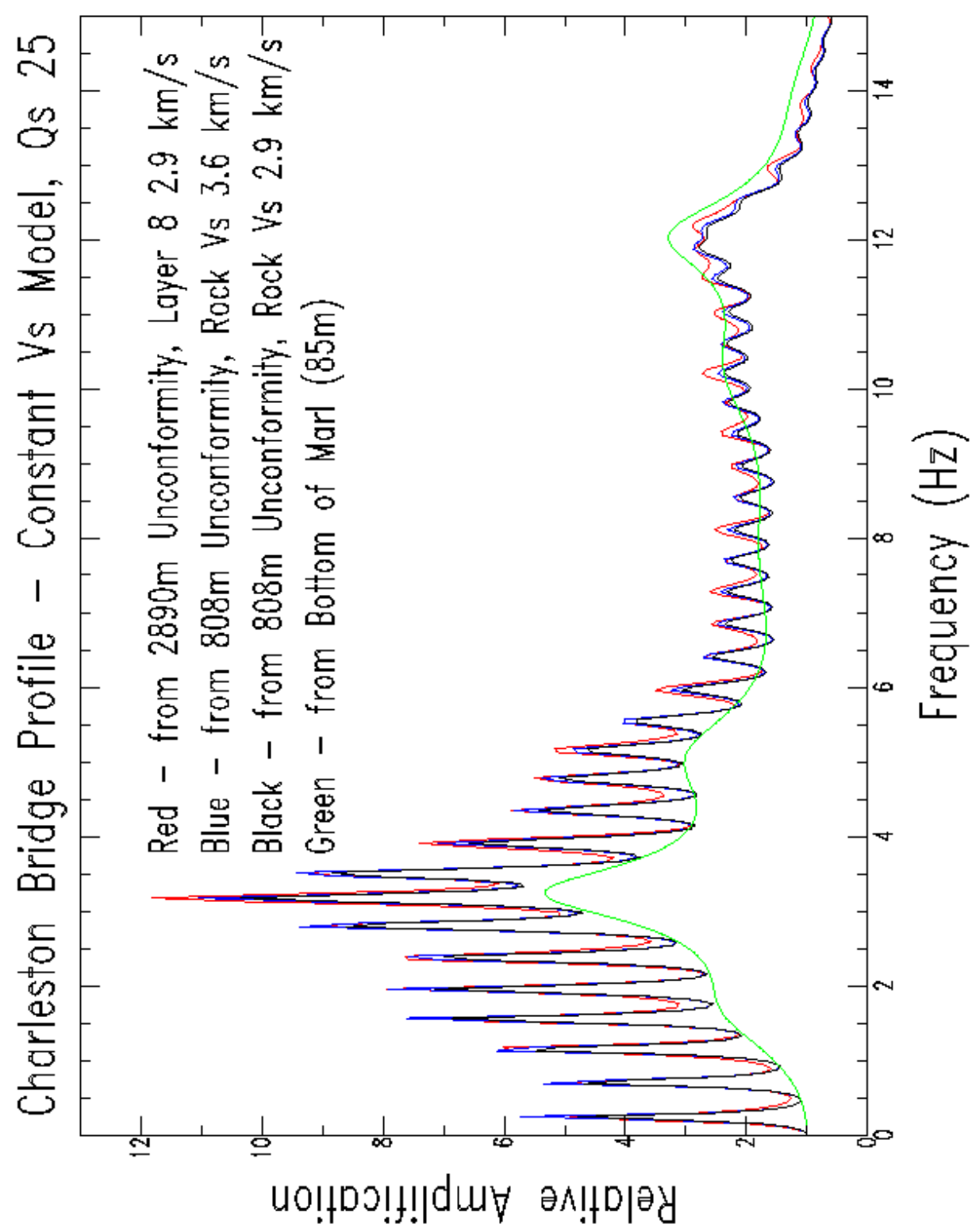

Figure 19. Comparison of relative amplification spectrum at the ground surface from propagating rock ground motions from the basement unconformity at $2890 \mathrm{~m}(9,480 \mathrm{ft})$, the pre-Cretaceous unconformity at $808 \mathrm{~m}(2,500 \mathrm{ft})$, and the bottom of the Cooper Marl at $85 \mathrm{~m}(280 \mathrm{ft})$ for models with a constant Vs in layer 7 and with a Vs of $2.9 \mathrm{~km} / \mathrm{s}(9,500 \mathrm{ft} / \mathrm{s})$ for layer 8 of Table 1, except for one model with a rock Vs of $3.6 \mathrm{~km} / \mathrm{s}(11,800 \mathrm{ft} / \mathrm{s})$ for layer 8 of Table 1 . Qs = 25 in layers 13. 


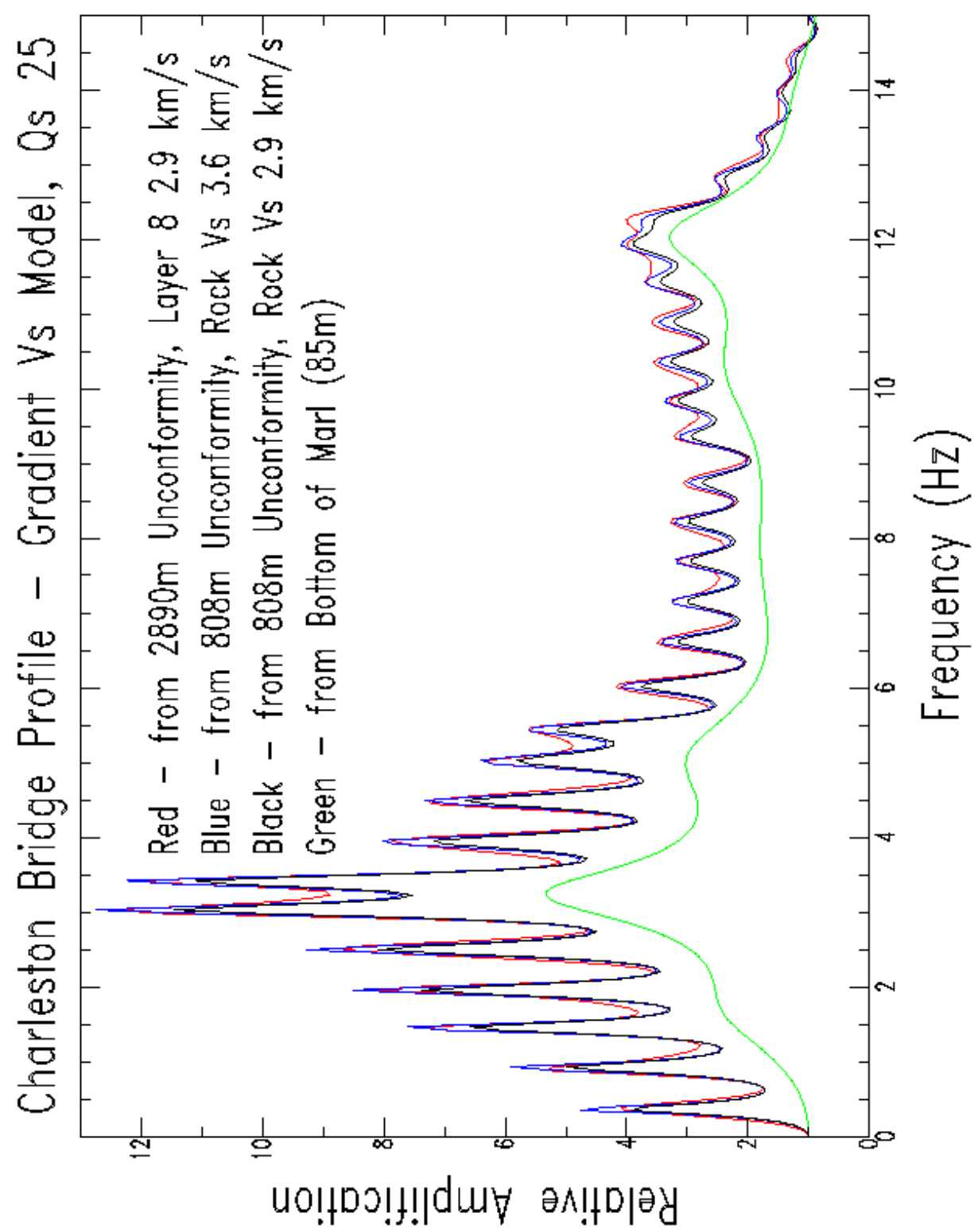

Figure 20. Comparison of relative amplification spectrum at the ground surface from propagating rock ground motions from the basement unconformity at $2890 \mathrm{~m}(9,480 \mathrm{ft})$, the pre-Cretaceous unconformity at $808 \mathrm{~m}(2,500 \mathrm{ft})$, and the bottom of the Cooper Marl at $85 \mathrm{~m}(280 \mathrm{ft})$ for models with a gradient Vs in layer 7 and with a Vs of $2.9 \mathrm{~km} / \mathrm{s}(9,500 \mathrm{ft} / \mathrm{s})$ for layer 8 of Table 1, except for one model with a rock Vs of $3.6 \mathrm{~km} / \mathrm{s}(11,800 \mathrm{ft} / \mathrm{s})$ for layer 8 of Table 1 . Qs $=25$ in layers 13. 